\title{
Borsa İstanbul' da 2013-2018 Yılları Arasında İlk Kez Halka Arz Edilen Payların Kısa Dönem Fiyat Performanslarının İncelenmesi (Research of Short-Run Price Performance of Initial Public Offering Shares between 2013-2018 in Borsa Istanbul)
}

\author{
Göksenin YAŞAR iD a Burak TERIM ${ }^{\text {iD }}{ }^{b}$ Cevdet KAYALI ${ }^{\text {iD }}$ c \\ a Bilim Uzmanı. gokseninyasar@gmail.com \\ b Celal Bayar Üniversitesi, İktisadi ve İdari Bilimler Fakültesi, İşletme Bölümü, Manisa, Türkiye. burak.terim@cbu.edu.tr \\ c İzmir Demokrasi Üniversitesi, İktisadi ve İdari Bilimler Fakültesi, İşletme Bölümü, İzmir, Türkiye. calptekin.kayali@idu.edu.tr
}

\begin{tabular}{|c|c|}
\hline MAKALE BİLGİsİ & ÖZET \\
\hline $\begin{array}{l}\text { Anahtar Kelimeler: } \\
\text { İlk Halka Arz } \\
\text { Yüksek Fiyatlama }\end{array}$ & $\begin{array}{l}\text { Amaç - Bu çalışmanın amacı Sermaye Piyasası Kurulu (SPK) tarafından } 2013 \text { yılında yapılan } \\
\text { düzenleme sonrası, sermayenin tabana yayılmasını ve anonim ortaklıkların önemli bir finansman } \\
\text { olanağına kavuşmasını sağlayan halka arzlarda, halka arz edilen şirket hisse senetleri için düşük } \\
\text { fiyatlama olgusunun varlığının incelenmesidir. }\end{array}$ \\
\hline $\begin{array}{l}\text { Gönderilme Tarihi } 29 \text { Eylül } \\
2020\end{array}$ & $\begin{array}{l}\text { Yöntem - Bu çalışmada halka arz edilen hisse senetlerinin ele alınan periyotlardaki dönem sonu ve } \\
\text { dönem başı fiyatları incelenerek performans analizi yapılmış ve literatürdeki diğer çalışmalarla } \\
\text { karşılaştıılmıştır. Hisse senetlerinin fiyat performansları, piyasayı etkileyen makro faktörlerden } \\
\text { arındırılarak hesaplanmaya çalışılmıştır. Fiyat performansları ölçülürken ham getiriler ve } \\
\text { düzeltilmiş artık getirileri de göz önünde bulundurularak BIST } 100 \text { endeksi verilerinden } \\
\text { yararlanılmıştır. }\end{array}$ \\
\hline $\begin{array}{l}\text { Revizyon Tarihi } 8 \text { Aralık } 2020 \\
\text { Kabul Tarihi } 15 \text { Aralık } 2020\end{array}$ & $\begin{array}{l}\text { Bulgular - Sermaye piyasası kurulu tarafından } 2013 \text { yılında yapılan halka arz düzenlemesi } \\
\text { sonrasında, 2013-2018 yılları arasında Borsa İstanbul A.Ş. (BİST)' de ilk defa halka arz olunan } 50 \\
\text { şirketin hisse senetlerinin ilk işlem günündeki fiyat performansları ve ilk } 30 \text { günlük fiyat } \\
\text { performansları yıllara, işlem gördükleri pazara ve BIST } 100 \text { endeksine göre incelenmiştir. Elde } \\
\text { edilen bulguların diğer gelişmiş, gelişmekte olan piyasalarda ve geçmiş yıllar veri setleri ile yapıllmış } \\
\text { diğer çalışmalardan farklılık gösterdiği gözlenmiştir. }\end{array}$ \\
\hline & $\begin{array}{l}\text { Tartışma - Bir şirketin hisse senetlerini birincil piyasada halka arz ederken belirleyeceği hisse senedi } \\
\text { fiyatı, ekonominin içinde bulunduğu duruma, sektördeki durumuna ve yatırımclların o dönemdeki } \\
\text { sermaye piyasalarına olan ilgisine bağlıdır. Bu bağlamda hisse senetleri halka arz edilen 2013-2018 } \\
\text { yılları arasındaki şirketlerin, şirketin sektördeki büyüklüğü, sermaye piyasası içindeki konumu ve } \\
\text { endeksteki ağırlığı, arz fiyatını ve ilk } 30 \text { günlük fiyat performansını etkilemekte olup, bu etkiler } \\
\text { araştırılabilir. }\end{array}$ \\
\hline
\end{tabular}

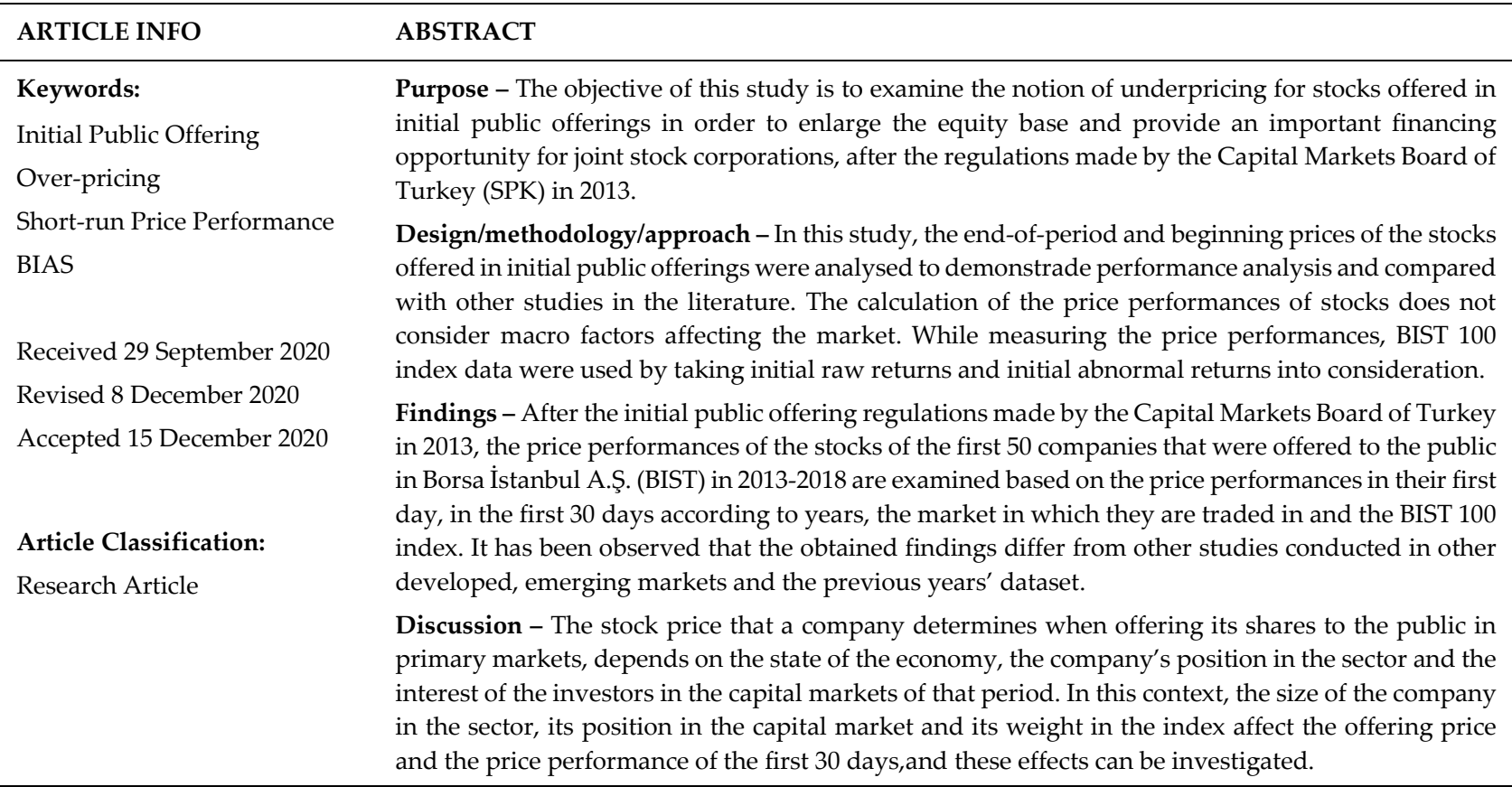




\section{GİRIŞ}

Şirketlerin en önemli sermaye kaynaklarından birisi de kuşkusuz halka arzlardan elde edilen fonlardan oluşmaktadır. Şirket açısından halka arzlar (birincil piyasalarda) işletme sermayesinin finansmanında ya da aktiflerinin finansmanında kullanılarak finansman maliyetlerini azaltmasıyla (alternatif maliyet) rekabet ve büyüme stratejileri bakımından kısa ve uzun dönemde önemlidir.

Halka arzların menkul kıymet yatırımcıları için önemi ise ilk halka arz edilen hisse senedi fiyatı ile fiyat değişikliklerinden sağlayacakları kısa veya uzun dönemdeki getiridir. Özellikle de yatırımcılar açısından halka arzlardaki fiyatın, kısa ve uzun dönemde sağlayacakları getiriyi doğru öngörebilmeleri açısından önemi büyüktür. Bu bakımdan ilk halka arzlar finans alanında araştırmacılar açısından gelişmiş ya da gelişmekte olan ülke piyasalarında ilgiyle incelenen bir konu olmuştur.

"Payları halka arz edilmiş olan veya halka arz edilmiş sayılan anonim ortaklıklar, halka açık ortaklık olarak tanimlanır"(SPK, 2016:1).

“Ortak sayısı 500'ün altında olan ortaklıklar ve daha önce halka arzı gerçekleşmemiş anonim ortaklıkların ilk kez yapacağı halka arz "Halka Açılma" olarak ifade edilmektedir. Payları halka arz edilmiş ortaklıkların, payların tekrar halka arz etmelerine "İkincil Halka Arz" denilmektedir" (SPK, 2018).

"Şirketlerin paylarını halka arz etme şekli koşullara bağlı olarak değişebilmektedir. Şirketler, mevcut sermayeyi temsil eden payların bir kısmını ortak satışı şeklinde halka arz edebildiği gibi sermaye artırımı yoluna giderek mevcut ortakların rüçhan haklarını kısıtlamak suretiyle de halka arzı tercih edebilir veya her iki yöntemi birlikte uygulayabilir"' (SPK, 2016:1).

Bir şirketin hisse senetlerini birincil piyasada halka arz ederken belirleyebileceği hisse senedi fiyatı arz şekline (sermaye artırımı, ortak satışı gibi), piyasa koşullarına, yatırımcıların hisse senedi piyasasına olan ilgilerine gibi birçok etkene bağlı iken, halka arz sonrası ilk gün fiyatını etkileyen faktörler ise piyasa koşulları, şirketin yapısı ve yatırımcı profili olarak açıklanabilir.

Halka arzlarda hisse senetlerinin ilk işlem gününde piyasanın üzerinde bir getiri elde etmesi piyasa değerinin (gerçek değerinin) altında fiyatlanmasına bağlıdır ve bu durum "düşük fiyatlama" olarak adlandırılmaktadır. Düşük fiyatlama tekniğinin temel varsayımı kuşkusuz yatııımcıların kısa vadede taleplerinin karşılanması ve şirketlerin de halka arzla hedefledikleri fon tutarına ulaşmaları olarak ifade edilebilir.

Halka arzları artırmak suretiyle şirketlerin sermaye piyasasının sunduğu imkanlardan yararlanmasına katkıda bulunmak amacıyla, Borsa İstanbul A.Ş. , Sermaye Piyasası Kurulu, İstanbul Sanayi Odası, Türkiye Sermaye Piyasası Aracı Kuruluşları Birliği ve Türkiye Odalar ve Borsalar Birliği tarafından 07.08.2008 tarihinde bir işbirliği protokolü imzalanmıştır. 2010 yılında yürürlüğe giren bu protokol ile birlikte halka arz seferberliği çerçevesinde 73 şirket halka arz olmuştur.

Halka arz seferberliğinde halka arz olan firma paylarının arz sonrasında gösterdiği fiyat performansları eleştiri konusu olmuş, 2013 yılında SPK tarafından halka arza ilişkin düzenlemelere gidilmiştir. Bu çalışmanın amacı bu düzenleme sonrası, halka arzlarda, halka arz edilen şirket hisse senetleri için eleştirilere konu düşük fiyatlama olgusunun varlığının incelenmesidir.

Halka açılan anonim ortaklıkların hisse senetlerinin fiyat performansı finans literatüründe oldukça ilgi gösterilen bir araştırma konusu olmuştur. Yapılan çalışmalarda üç anomali üzerinde durulmuştur. Düşük fiyatlama, uzun dönem ve kısa dönem fiyatlamalar incelenmiştir. Bu çalışma da, Borsa İstanbul A.Ş.' de ilk defa halka arzı gerçekleştirilen paylarda düşük veya yüksek fiyatlamanın varlığı ve bu payların kısa dönemde göstereceği performans incelenmeye çalışılmıştır.

\section{KAVRAMSAL ÇERÇEVE}

\section{1. İlk Halka Arz Fiyatlaması Kavramı}

“ilk halka arzların fiyatlamaları, finans literatürünün en önemli ve en sıcak konularından olup, ilk halka arzların düşük fiyatlandırıldığı üzerine bir uzlaşı vardır. Halka arz fiyatının, payın borsada işlem gördüğü ilk günkü kapanış fiyatının altında kalması, söz konusu payın düşük fiyatlandırılarak halka arz edildiği anlamına gelmektedir" (Özer, 2014: 6). 
“Finans literatüründe, ortaklık paylarının gerçek değerinin altında bir fiyatla satışa sunulması "düşük fiyatlama", gerçek değerinin üstünde bir fiyattan satışa sunulması ise "yüksek fiyatlama" olarak adlandırılmaktadır" (Ünlü ve Ersoy, 2008: 244).

“ilk halka arzlarda payların performanslarının değerlendirilmesine ilişkin yapılan araştırmaların büyük bir çoğunluğu, halka ilk kez arz edilen payların düşük fiyatlandırıldığını ortaya koymaktadır. Bu durum Halka arza katılan yatırımcıların, halka arzın ilk günlerinde bu hisse senetlerini ikincil piyasada satarak piyasa getirisinin üzerinde anormal bir getiri elde edeceği anlamına gelmektedir" (Erpek, 2006: 14).

\section{2. İlk Halka Arz Fiyatlamasına İlişkin Literatür}

İlk kez halka arz edilen payların borsa fiyat performanslarına ilişkin olarak Türkiye' de ve uluslararasında birçok çalışma yapılmış ve önemli bulgulara ulaşılmıştır. Çalışmalar, ilk halka arzların performanslarını "kısa dönem" ve "uzun dönem" fiyat performansları şeklinde iki zaman diliminde incelemiştir.

İlk defa halka arz edilen hisse senetlerinin, kısa dönem fiyat performanslarını ölçümlemek için yapılan çalışmalarda, genellikle ilk halka arzların, halka arz edildikleri ilk gün piyasa performansının üzerinde bir getiri sağladığını doğrulayan önemli sayıda sonuç elde edilmiştir.

“Düşük fiyatlama kavramı çok kısa dönem için kullanılmaktadır. Stoll ve Curley (1970), Logue (1973), Reilly (1973) ve Ibbotson (1975) çalışmalarında, halka arz fiyatının ilk gün kapanış fiyatının alınnda kaldığını gösteren ilk çalışmalardır" (Özer, 2014: 6).

“ilk defa halka arz edilen payların fiyat performansları üzerine yapılan araştırmaların sonuçlarına göre, araştırma yapılan piyasaların büyük çoğunluğunda ilk defa halka arz edilen payların düşük fiyatlandırıldığ 1 gözlenmektedir" (Ünlü ve Ersoy, 2008:244).

Tablo 1' de çeşitli gelişmiş ve gelişmekte olan ülkelerde ilk halka arzların ilk gün getirileriyle ilgili yapılan çalışmalar sunulmuştur.

Tablo 1. Gelişmiş ve Gelişmekte Olan Ülkelerde Düşük Fiyatlama İle İlgili Çalışmalar (Loughran vd., 2020:2)

\begin{tabular}{|c|c|c|c|c|}
\hline Ülke & Yazarlar & $\begin{array}{c}\text { Halka Arz } \\
\text { Sayısı }\end{array}$ & Periyod & $\begin{array}{l}\text { Ort. İlk Gün } \\
\text { Getiriler (\%) }\end{array}$ \\
\hline Arjantin & Eijgenhuijsen\&Van Der Valk; Dealogic & 30 & $1991-2018$ & 5,7 \\
\hline $\mathrm{ABD}$ & Ibbotson, Sindelar \& Ritter; Ritter & 13.244 & $1960-2019$ & 16,90 \\
\hline Almanya & Ljungqvist; Rocholl; Vismara; Dealogic & 779 & 1978-2014 & 23,0 \\
\hline Avusturalya & Lee, Taylor \& Walter; Woo; Pham ; Dealic & 2.069 & $1976-2018$ & 19,8 \\
\hline Avusturya & Aussenegg; Dealogic & 106 & 1971-2018 & 6,2 \\
\hline Belçika & $\begin{array}{l}\text { Rogiers, Manigart \& Ooghe; Manigart Du } \\
\text { Mortier; Dealogic }\end{array}$ & 154 & 1984-2017 & 11,0 \\
\hline $\begin{array}{l}\text { Birleşik Arap } \\
\text { Emirlikleri } \\
\end{array}$ & Alanzi \& Al-Zoubi & 24 & 2003-2010 & 270,1 \\
\hline Brezilya & $\begin{array}{l}\text { Aggarwal, Leal \& Hernandez; Saito; Ushisima; } \\
\text { Dealogic }\end{array}$ & 303 & 1979-2018 & 30,3 \\
\hline Bulgaristan & Nikolov & 9 & 2004-2007 & 36,5 \\
\hline Çin & $\begin{array}{l}\text { Chen, Choi, \& Jiang; Jia, Xie, Zhang, \& Ritter; } \\
\text { Qian; Jin }\end{array}$ & 3.798 & 1990-2019 & 169,5 \\
\hline Danimarka & Jakobsen \& Sorensen; Ritter & 173 & 1984-2017 & 7,4 \\
\hline Endonezya & Suherman & 531 & $1990-2017$ & 26,4 \\
\hline Fas & Alami Talbi; Hearn & 33 & $2000-2011$ & 33,3 \\
\hline Filipinler & Sullivan \& Unite; Dealogic & 173 & $1987-2018$ & 17,3 \\
\hline Finlandiya & Keloharju; Dealogic & 209 & 1971-2018 & 14,2 \\
\hline Fransa & $\begin{array}{l}\text { Husson \& Jacquillat; Leleux \& Muzyka; } \\
\text { Paliard \& Belletante; Derrien \& Womack; } \\
\text { Chahine; Ritter; Vismara; Dealogic }\end{array}$ & 834 & 1983-2017 & 9,7 \\
\hline $\begin{array}{l}\text { Güney } \\
\text { Afrika }\end{array}$ & $\begin{array}{l}\text { Page \& Reyneke; ali, Subrahmanyam \& } \\
\text { Gleason; Dealogic }\end{array}$ & 342 & $1980-2018$ & 17,2 \\
\hline
\end{tabular}


G. Yaşar - B. Terim - C. Kayalı 12/4 (2020) 3965-3980

\begin{tabular}{|c|c|c|c|c|}
\hline Hindistan & Marisetty and Subrahmanyam; Dealogic & 3.145 & 1990-2017 & 85,2 \\
\hline Hollanda & $\begin{array}{l}\text { Wessels; Eijgenhuijsen \& Buijs; Jenkinson, } \\
\text { Ljungqvist \& Wilhelm; Ritter }\end{array}$ & 212 & 1983-2017 & 13,3 \\
\hline Hong Kong & $\begin{array}{l}\text { Mc Guinness; Zhao \& Wu; Ljungqvist \& Yu; } \\
\text { Fung, Gul, and Radhakrishnan; Dealogic }\end{array}$ & 2.042 & $1980-2017$ & 44,5 \\
\hline İngiltere & Dimson; Vismara; Levis; Doukas \& Hoque & 5.185 & 1959-2016 & 15,8 \\
\hline İran & Bagherzadeh & 279 & 1991-2004 & 22,4 \\
\hline İrlanda & Dealogic & 38 & 1991-2013 & 21,6 \\
\hline İspanya & Ansotegui \& Fabregat; Alvarez Otera; Dealogic & 199 & 1986-2018 & 9,2 \\
\hline İsrail & $\begin{array}{l}\text { Kandel, Sarig \& Wohl; Amihud \& Hauser; } \\
\text { Ritter }\end{array}$ & 348 & 1990-2006 & 13,8 \\
\hline İsveç & Rydqvist; Schuster; De Ridder & 405 & 1980-2015 & 25,9 \\
\hline İsviçre & $\begin{array}{l}\text { Kunz, Drobetz, Kammermann \& Walchli; } \\
\text { Dealogic }\end{array}$ & 164 & $1983-2018$ & 25,2 \\
\hline İtalya & $\begin{array}{l}\text { Arosio, Giudici \& Paleari; Cassia, Paleari \& } \\
\text { Redondi; Vismara; Dealogic }\end{array}$ & 413 & $1985-2018$ & 13,1 \\
\hline Japonya & $\begin{array}{l}\text { Fukuda; Dawson \& Hiraki; Hebner \& Hiraki; } \\
\text { Pettway \& Kaneko; Hamao, Packer \& Ritter; } \\
\text { Kaneko \& Pettway; Kaneko; Dealogic }\end{array}$ & 3.756 & 1970-2019 & 46,8 \\
\hline Kanada & $\begin{array}{l}\text { Jog \& Riding; Jog \& Srivastava; Kryzanowski, } \\
\text { Lazrak \& Rakita; Ritter }\end{array}$ & 758 & 1971-2017 & 6,4 \\
\hline Kibris & $\begin{array}{l}\text { Gounopoulos, naunis, and Stylianides; } \\
\text { Chandriotis }\end{array}$ & 73 & 1997-2012 & 20,3 \\
\hline Kore & $\begin{array}{l}\text { Dhatt, Kim \& Lim; Ihm; Choi \& Heo; } \\
\text { Moshairan \& Ng; Cho; Cho; Joh; Dealogic; Lee }\end{array}$ & 2.007 & $1980-2018$ & 55,2 \\
\hline Lübnan & Al-Ali and Braik & 53 & 1999-2008 & 149,0 \\
\hline Malezya & Isa; Isa \& Yong; Yong; Ma; Dealogic & 562 & 1980-2018 & 51,0 \\
\hline Mauritius & Bundoo & 40 & 1989-2005 & 15,2 \\
\hline Meksika & $\begin{array}{l}\text { Aggarwal, Leal \& Hernandez; Eijgenhuijsen \& } \\
\text { Van Der Valk; Villarreal }\end{array}$ & 149 & $1987-2017$ & 9,9 \\
\hline Misır & Omran; Hearn & 74 & 1990-2017 & 9,4 \\
\hline Nijerya & Ikoku; Achua; Dealogic & 125 & 1989-2017 & 12,8 \\
\hline Norveç & $\begin{array}{l}\text { Emilsen, Pedersen \& Saettem; Liden; Dealogic; } \\
\text { Fjesme }\end{array}$ & 266 & 1984-2018 & 6,7 \\
\hline Pakistan & Mumtaz & 80 & $2000-2013$ & 22,1 \\
\hline Polonya & Jelic \& Briston ; Woloszyn ; Sieradzki & 350 & 1991-2019 & 11,7 \\
\hline Portekiz & Almeida \& Duque; Dealogic & 33 & $1992-2017$ & 11,5 \\
\hline Rusya & Dealogic & 64 & $1999-2013$ & 3,3 \\
\hline Singapur & Lee, Taylor \& Walter; Dawson; Dealogic & 687 & 1973-2017 & 25,8 \\
\hline Srilanka & Samarakoon; Dealogic & 134 & $1987-2018$ & 28,9 \\
\hline $\begin{array}{l}\text { Suudi } \\
\text { Arabistan }\end{array}$ & Al-Anazi, Forster \& Liu; Alqantani & 80 & 2003-2011 & 239,8 \\
\hline Şili & $\begin{array}{l}\text { Aggarwal, Leal \& Hernandez; Celis \& } \\
\text { Maturana; Dealogic }\end{array}$ & 86 & 1982-2018 & 6,9 \\
\hline Tayland & $\begin{array}{l}\text { Wethyavivorn \& Koo-smith; Lonkani \& } \\
\text { Tirapat; Ekkayokkaya and Pengniti; } \\
\text { Vithessonthi; Dealogic }\end{array}$ & 697 & $1987-2018$ & 40,0 \\
\hline Tayvan & Chen; Chiang & 1.915 & 1980-2019 & 37,2 \\
\hline Tunus & Hearn, Dealogic & 38 & 2001-2014 & 21,7 \\
\hline Türkiye & $\begin{array}{l}\text { Kıymaz; Durukan; İnce; Küçükkocaoğlu; Elma; } \\
\text { Dealogic }\end{array}$ & 404 & $1990-2014$ & 9,6 \\
\hline Vietnam & Tran, Le \& Hoang; Nguyen, Trinh, \& Ninh & 167 & $2005-2017$ & 33,3 \\
\hline
\end{tabular}


G. Yaşar - B. Terim - C. Kayalı 12/4 (2020) 3965-3980

\begin{tabular}{|l|l|c|c|c|}
\hline Yeni Zelanda & Vos \& Cheung; Camp \& Munro; Alqantani & 269 & $1979-2018$ & 15,9 \\
\hline Yunanistan & $\begin{array}{l}\text { Nounis, Kazantzis \& Thomas; Thomadakis, } \\
\text { Gounopoulos\& Nounis }\end{array}$ & 373 & $1976-2013$ & 50,8 \\
\hline
\end{tabular}

Türkiye' de yapılan araştırmaların çoğunluğu kısa dönem performans ve düşük fiyatlama üzerine yapılmıştır. Ülkemizde halka arz edilen payların kısa dönemli performans araştırmalarının birçoğunda düşük fiyatlamanın gerçekleştiği gözlemlenmiştir.

Tablo 2' de Türkiye' de yapılan halka arzların kısa dönemli getirileriyle ilgili yapılan çalışmalardaki ilk gün getirileri sunulmuştur.

Tablo 2. Türkiye' de Yapılan Halka Arzların Kısa Dönemli Getirileriyle İlgili Yapılan Çalışmalar

\begin{tabular}{|l|c|c|c|}
\hline Yazarlar & Halka Arz Sayısı & Periyod & Ort. İlk Gün Getiriler (\%) \\
\hline Aydoğan ve Yıldırım (1991) & 33 & $1989-1991$ & 1,2 \\
\hline Akkaşoğlu (1992) & 35 & $1990-1991$ & 12,5 \\
\hline Erdem (1993) & 64 & $1989-1992$ & 18,8 \\
\hline Kıymaz (1996) & 88 & $1990-1995$ & 12,2 \\
\hline Kıymaz (1997 (a)) & 39 & $1989-1995$ & 15,3 \\
\hline Özer (1999) & 89 & $1989-1994$ & 12,41 \\
\hline Güner, Önder, Danışoğlu (1999) & 118 & $1993-1998$ & 7 \\
\hline Kıymaz (2000) & 163 & $1990-1996$ & 13,1 \\
\hline Durukan (2002) & 173 & $1990-1997$ & 14,61 \\
\hline Aydoğan, Aktaş ve Karan (2003) & 190 & $1992-2000$ & 9,2 \\
\hline Teker ve Ekit (2003) & 34 & 2000 & 9,78 \\
\hline Özden (2005) & 134 & $1990-1997$ & 7,1 \\
\hline Yalçıner (2006) & 93 & $1997-2004$ & 7,2 \\
\hline Sevim Akkoç (2006) & 185 & $1990-1999$ & 10,69 \\
\hline Bildik ve Yılmaz (2008) & 244 & $1990-2000$ & 5,94 \\
\hline Altan ve Hotamış (2008) & 67 & $2000-2006$ & 6,78 \\
\hline Küçükkocaoğlu (2008) & 217 & $1993-2005$ & 9,6 \\
\hline Eraydın (2008) & 88 & $1999-2007$ & 7,3 \\
\hline Daştan (2008) & 25 & $2004-2007$ & 5,8 \\
\hline Ünlü ve Ersoy (2008) & 112 & $1995-2008$ & 6,52 \\
\hline Ünlü vd. (2009) & 136 & $1992-2005$ & 8,7 \\
\hline Kırkulak (2010) & 150 & $1995-2004$ & 8,26 \\
\hline Tükel (2010) & 42 & $2000-2007$ & 10,94 \\
\hline Çelik ve Sağlam (2011) & 40 & $1993-2006$ & 11,3 \\
\hline Otlu ve Ölmez (2011) & 53 & $2006-2011$ & 6,69 \\
\hline Özer (2014) & 71 & $2011-2013$ & 4,81 \\
\hline Yazaroğlu (2015) & 106 & $2010-2014$ & 3,09 \\
\hline Bayram (2015) & 92 & $1999-2009$ & 6,85 \\
\hline
\end{tabular}

\section{YÖNTEM}

\subsection{Araştırma Örneklemi ve Modeli}

Bu çalışmanın amacı Sermaye Piyasası Kurulu (SPK) tarafından 2013 yılında yapılan düzenleme sonrası halka arzlarda, halka arz edilen şirket hisse senetleri için düşük fiyatlama olgusu varlığının incelenmesidir.

Bu çalışmada 2013-2018 yılları arasında Borsa İstanbul A.Ş.' de halka açllan 50 anonim şirkete ilişkin ortaklık paylarının ilk otuz günlük fiyat hareketlerini yıllara, halka arzı yapılan payların işlem gördügü pazarlara ve BİST 100 Endeksine göre incelemesi yapılmıştır. Çalışmaya konu olan veriler Borsa İstanbul A.Ş. ve Finnet 2000'nin internet sitesinden alınmıştır.

Hesaplamalarda pay fiyatları olarak düzeltilmemiş kapanış fiyatları baz alınmış, endeks verisi olarak ise Borsa İstanbul A.Ş.' nin 100 endeksinin kapanış verileri kullanılmıştır. Verilerde şirketlerin halka açıldığı gün 0. Gün 
olarak alınmış, 1. Gün fiyatları Borsada işlem görmeye başladıkları tarihin ertesi günkü kapanış fiyatları olarak alınmıştır.

2013 - 2018 yıllarında ilk kez halka arzı gerçekleştirilen şirket sayısı 51 olup, 2014 yılında halka arz edilen Mutlucan Tuz Madencilik İnşaat Turizm Otomotiv Petrol Nakliye Sanayi ve Ticaret A.Ş.' ye yeterli talep oluşmaması nedeniyle halka arzı iptal edilmiş bu yüzden çalışmamızda değerlendirme dışı bırakılmıştır.

Borsa İstanbul A.Ş.' de 30.11.2015 tarihinden itibaren Ulusal Pazar, II. Ulusal Pazar kaldırılmış ve Kurumsal Ürünler Pazarının mevcut yapısı değiştirilmiştir. Yeni düzenlemede Ana Pazar ve Yıldız Pazar kurulmuş, Kurumsal Ürünler Pazarının ismi de Kolektif Yatırım Ürünleri ve Yapılandırılmış Ürünler Pazarı olarak değiştirilmiştir. Çalışmamızda ilk defa halka arz olan şirketlerden Ulusal Pazarda yer alanlar Ana Pazarda, II. Ulusal Pazarda yer alan şirketler de Yıldız Pazarda değerlendirilmiştir.

Çalışmamızda payların kısa dönem fiyat performans ölçümünde kullanılan başlangıç getirisi iki farklı şekilde hesaplanmıştır. Bunlardan ilki ham getiri (initial raw return) diğeri Borsa İstanbul A.Ş. 100 Getiri Endeksine göre düzeltilmiş artık getiridir (initial abnormal return).

Başlangıç ham getirisi, ilk halka arz edilmiş payların halka arz fiyatı ile borsada işlem gördügü ilk günün kapanış fiyatı (ikinci seans kapanı̧ fiyatı) arasındaki yüzdesel farktır. Çalışmada başlangı̧̧ ham getirisi aşağıdaki şekilde hesaplanmıştır. (Bayram, 2015:166)

$r_{i, t}=\left(P_{i, t} / P_{i, \dot{I} H A F}\right)-1$

$r_{i, t}=$ i Şirketinin t İlk Halka Arz Günü Başlangıç Ham Getirisi

$P_{i, t}=$ i Şirketinin t İlk İşlem Günü Kapanış Fiyatı

$P_{i, \dot{I} H A F}=$ i Şirketinin İlk Halka Arz Fiyatı

Başlangıç ham getirilerden elde edilen sonuç, ilgili t işlem gününde İHA (İlk Halka Arz) şirketinin bulunduğu sektöre veya genel ekonomik bir gelişmeden kaynaklı özgün bir değer alabilecektir. Bu nedenle sonucun $t$ günü için piyasayı etkileyen makro faktörlerden arındırılarak, ilgili pay senedine özgü performansı yansıtmasını sağlamak amacı ile artık getiriler hesaplanmıştır. Artık getiri ifadesiyle, ilk halka arzı gerçekleştirilen pay senedinin ham getirisinin, aynı dönem için hesaplanan Borsa İstanbul A.Ş. 100 Getiri Endeksi getirisini aşan kısmı ifade edilmek istenmektedir. Başlangıç Artık Getirisinin hesaplanmasında öncellikle karşılaştırma ölçütü olan Borsa İstanbul 100 Endeks Getirisi her halka arz şirketinin t ilk halka arz günü için aşağıdaki eşitlik ile hesaplanmıştır. ( Bayram, 2015:167)

$r_{B I S T 100, t=\left(P_{B I S T 100, t} / P_{i, t-1}\right)-1}$

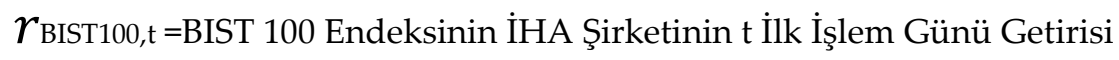

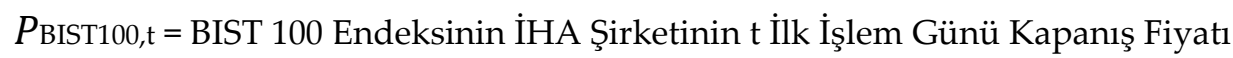

PBIST100,t-1 = BIST 100 Endeksinin İHA Şirketinin t İlk İşlem Gününden Önceki Gün Kapanış Fiyatı

(1) ve (2) no'lu eşitlikler kullanılarak her bir İHA şirketi pay senedinin başlangıç artık getirisi ise aşağıdaki eşitlikle hesaplanmıştır.

$\operatorname{ar}_{\mathrm{i}, \mathrm{t}}=\mathrm{ri}_{\mathrm{i}, \mathrm{t}}-\mathrm{rBIST}_{100, \mathrm{t}}$

$a r_{i, t}=i$ Şirketinin t ilk işlem günü Artık Getirisi

$r_{i, t}=i$ Şirketinin t, İlk Halka Arz Günü Başlangıç Ham Getirisi

rBIST100,t = BIST 100 Endeksinin t İlk İşlem Günü Getirisi

$\mathrm{n}$ adet ilk halka arz şirketinden oluşan eşit ağırlıklı bir portföy için $\mathrm{t}$ ilk halka arz gününde piyasa getirisine(BIST 100 Endeksi) göre düzeltilmiş ortalama artık getiriler ise aşağıdaki eşitlik ile hesaplanmıştır.

$\mathrm{AR}_{t}=1 / n \sum_{i=1}^{n} \mathrm{ar}_{\mathrm{i}, \mathrm{t}}$ 
G. Yaşar - B. Terim - C. Kayalı 12/4 (2020) 3965-3980

\subsection{Borsa İstanbul (BIST)' da 2013-2018 Yılları Arasında Gerçekleştirilen İlk Halka Arzlar}

2013 yılında SPK tarafından halka arza ilişkin düzenlemelere gidilmiştir. 2013-2018 yılları arasında 51 şirket halka arz olmuş, 1 şirketin halka arzı talep yetersizliğinden dolayı iptal olmuştur. 2013-2018 yılları arasında halka arz olan 5 firma gerekli yükümlülüklerini yerine getiremediklerinden kottan çıkartılmıştır.

Türkiye' de 1990-2018 Yılları arası halka arz olunan şirket sayısı Grafik 1' deki gibidir.

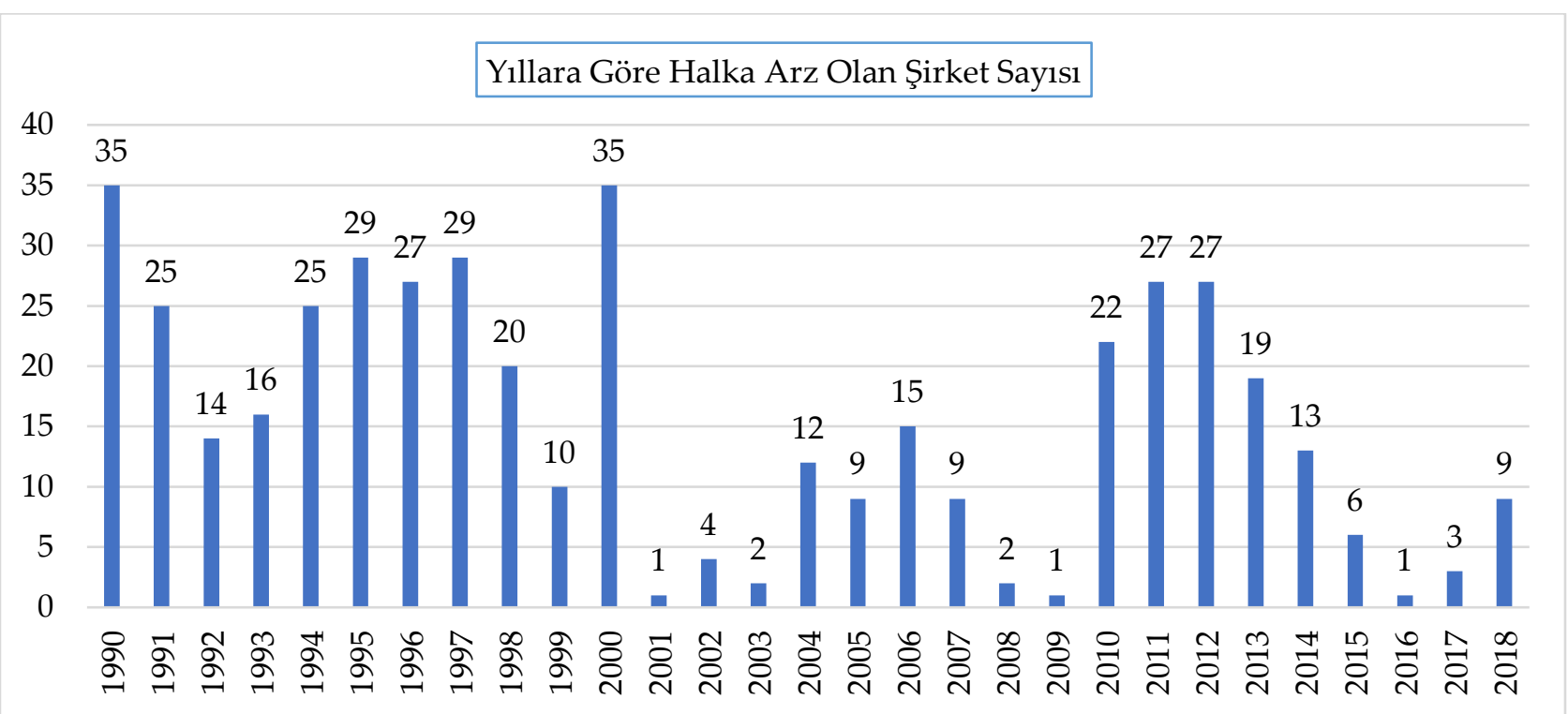

Grafik 1. Yıllar İtibariyle Halka Arz Olunan Şirket Sayısı

2013 Yılında Sermaye Piyasası Kurulu tarafından pay halka arzlarına özellikle fiyatlamaya yönelik ek düzenlemeler getirilmiştir. Bu düzenleme sonrası halka arzlarda dikkat çekici bir düşüş yaşanmıştır. Bu düzenlemelerle birlikte halka arz isteği azalmıştır denilebilir.

Türkiye' de 2013 - 2018 yılları arasında yapılan toplam 50 halka arzda, toplam \$2.910.819.756,09 kaynak elde edilmiş olup bunların yıllar ve işlem gördükleri pazarlar itibariyle dağılımları Grafik 2 ve Grafik 3 ile açıklanmaya çalışılmıştır.

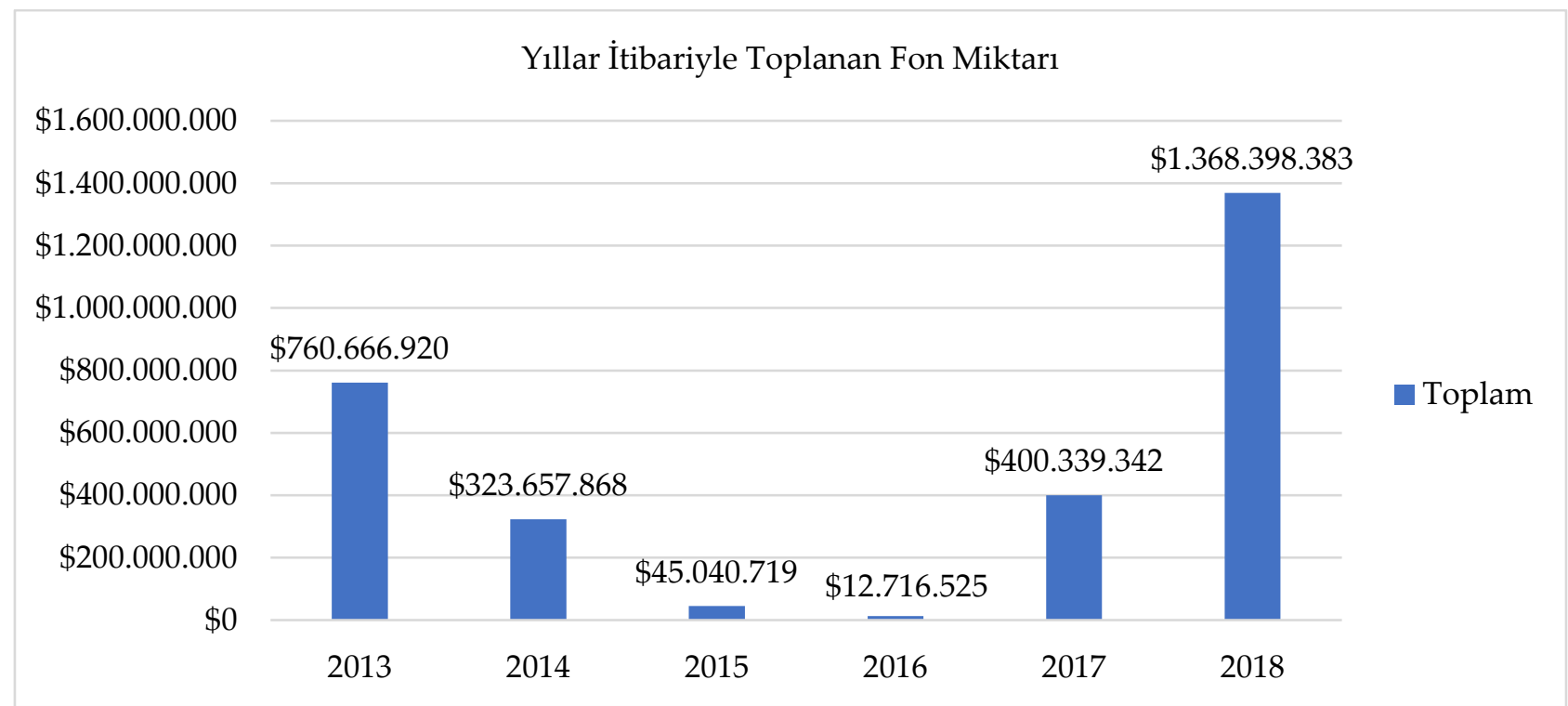

Grafik 2. Yıllar İtibariyle Toplanan Fon Miktarı (USD) 


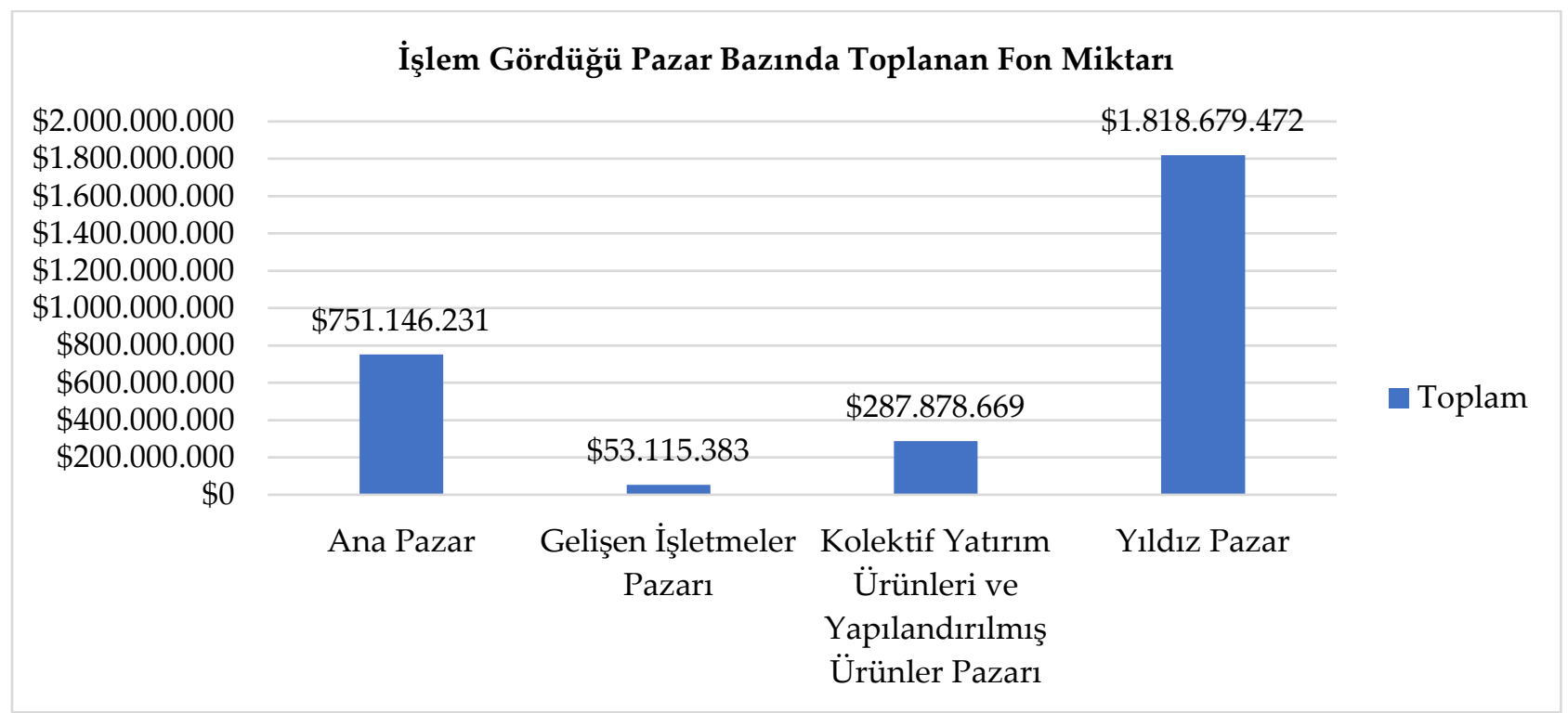

Grafik 3. İşlem Gördüğü Pazar Bazında Toplanan Fon Miktarı (USD)

2013-2018 yılları arasında en düşük toplanan fon miktarı 2015 yılında olurken en çok fon miktarı 2018 yılında toplanmıştır. Son yıllarda halka arzlara yatırımcı ilgisinin arttığı görülmektedir. Bu noktada 2018 yılında gerçekleştirilen Aselsan'ın ikincil halka arzının etkisinin de göz ardı edilmemesi gerekir.

Payların işlem gördüğü pazar bazında bakıldığında en düşük fon Gelişen İşletmeler Pazarında toplanırken, en çok fon miktarını da Yıldız Pazar'da işlem gören şirketler toplamıştır.

Halka arz olan firmaların işlem gördüğü pazarlara ilişkin dağılım ise Grafik 4' te görüldüğü gibidir.

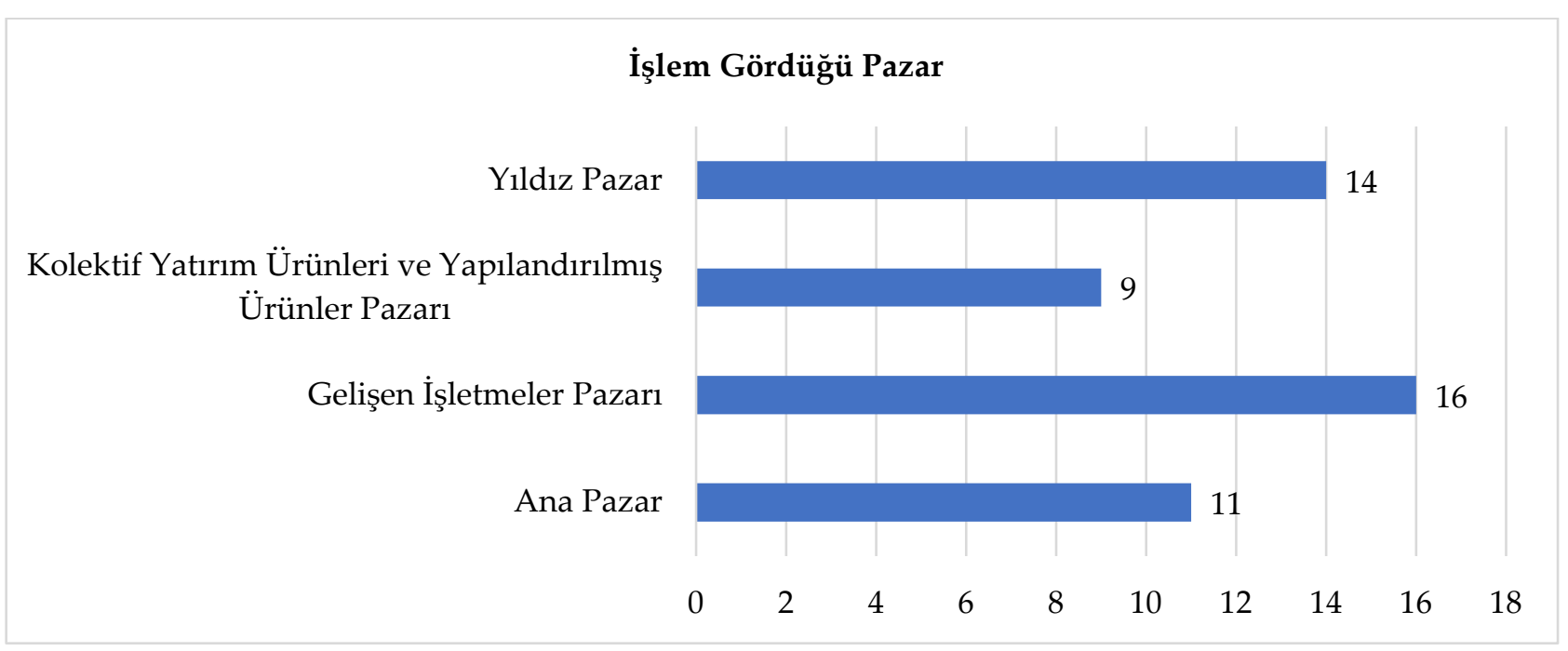

Grafik 4. Halka Arz Olan Firmaların İşlem Gördüğü Pazar Bazında Dağılımları

Halka ilk defa arz olan firmalar en çok Gelişen İşletmeler Pazarında yer almasına rağmen toplanan en düşük miktar yine bu pazarda işlem gören şirketler tarafından toplanmıştır.

\section{BULGULAR}

\subsection{3-2018 Yıllarında Yapılan İlk Halka Arzların Kısa Dönemli Performanslarının Analizi}

Çalışmada 2013-2018 yılları arasında ilk defa halka arz edilen 50 anonim ortaklığın paylarının ilk 30 işlem günündeki performansları yıllara, halka arzı yapılan payların işlem gördüğü pazarlara ve BİST100 Endeksinin getirisine göre analiz edilmiştir.

Yapılan çalışmada 2013-2018 yılları arası ilk halka arz olan ortaklık paylarının BíST 100 Endeksinden arındırılmış ilk gün artık getirisi -\%14,04 olmuştur. Çıkan sonuçlara göre 2013-2018 yılları arasında yüksek fiyatlama yapıldığı söylenebilir. Yıllara göre ilk 30 günlük AR değerleri Tablo 3’ teki gibidir. 
G. Yaşar - B. Terim - C. Kayalı 12/4 (2020) 3965-3980

Tablo 3. Yıllara Göre 30 Günlük AR (Artık Getiri) Değerleri

\begin{tabular}{|l|c|c|c|c|c|c|c|}
\hline AR Değeri & 2013 & 2014 & 2015 & 2016 & 2017 & 2018 & $\begin{array}{c}\text { Genel } \\
\text { Toplam }\end{array}$ \\
\hline 1. Gün & $-15,38 \%$ & $-23,20 \%$ & $-19,92 \%$ & $-11,91 \%$ & $-13,62 \%$ & $5,40 \%$ & $\mathbf{- 1 4 , 0 4 \%}$ \\
\hline 2. Gün & $1,84 \%$ & $-0,09 \%$ & $2,71 \%$ & $-2,57 \%$ & $-1,22 \%$ & $1,28 \%$ & $\mathbf{1 , 0 7 \%}$ \\
\hline 3. Gün & $-0,80 \%$ & $-0,08 \%$ & $1,51 \%$ & $-2,52 \%$ & $0,23 \%$ & $0,65 \%$ & $\mathbf{- 0 , 0 5 \%}$ \\
\hline 4. Gün & $1,38 \%$ & $-0,42 \%$ & $5,73 \%$ & $3,64 \%$ & $7,37 \%$ & $-1,69 \%$ & $\mathbf{1 , 2 8 \%}$ \\
\hline 5. Gün & $0,13 \%$ & $-0,47 \%$ & $-1,69 \%$ & $-1,53 \%$ & $1,54 \%$ & $0,40 \%$ & $\mathbf{- 0 , 1 4 \%}$ \\
\hline 6. Gün & $0,56 \%$ & $-0,25 \%$ & $-1,01 \%$ & $0,36 \%$ & $2,79 \%$ & $-1,57 \%$ & $\mathbf{- 0 , 0 9 \%}$ \\
\hline 7. Gün & $0,65 \%$ & $0,04 \%$ & $0,05 \%$ & $-1,18 \%$ & $-2,33 \%$ & $0,21 \%$ & $\mathbf{0 , 1 3 \%}$ \\
\hline 8. Gün & $-0,22 \%$ & $0,37 \%$ & $0,56 \%$ & $-0,19 \%$ & $0,30 \%$ & $0,70 \%$ & $\mathbf{0 , 2 2 \%}$ \\
\hline 9. Gün & $-0,91 \%$ & $-0,40 \%$ & $-0,61 \%$ & $-1,10 \%$ & $-3,48 \%$ & $0,54 \%$ & $\mathbf{- 0 , 6 4 \%}$ \\
\hline 10. Gün & $-0,11 \%$ & $-0,88 \%$ & $-0,32 \%$ & $-0,05 \%$ & $-3,62 \%$ & $0,74 \%$ & $\mathbf{- 0 , 3 9 \%}$ \\
\hline 11. Gün & $0,26 \%$ & $0,42 \%$ & $0,51 \%$ & $-0,47 \%$ & $0,45 \%$ & $-0,59 \%$ & $\mathbf{0 , 1 8 \%}$ \\
\hline 12. Gün & $-0,22 \%$ & $-0,15 \%$ & $1,72 \%$ & $0,19 \%$ & $-1,19 \%$ & $-1,60 \%$ & $\mathbf{- 0 , 2 7 \%}$ \\
\hline 13. Gün & $-0,45 \%$ & $1,07 \%$ & $-0,38 \%$ & $-0,83 \%$ & $-1,02 \%$ & $-0,02 \%$ & $\mathbf{- 0 , 0 1 \%}$ \\
\hline 14. Gün & $1,18 \%$ & $-0,38 \%$ & $-0,23 \%$ & $-1,36 \%$ & $0,26 \%$ & $0,36 \%$ & $\mathbf{0 , 3 5 \%}$ \\
\hline 15. Gün & $0,85 \%$ & $0,24 \%$ & $-0,60 \%$ & $-1,51 \%$ & $4,56 \%$ & $0,71 \%$ & $\mathbf{0 , 6 7 \%}$ \\
\hline 16. Gün & $1,47 \%$ & $-1,41 \%$ & $0,12 \%$ & $-0,45 \%$ & $-0,89 \%$ & $-0,89 \%$ & $\mathbf{- 0 , 0 4 \%}$ \\
\hline 17. Gün & $1,47 \%$ & $0,58 \%$ & $0,61 \%$ & $-0,34 \%$ & $-0,56 \%$ & $0,24 \%$ & $\mathbf{0 , 7 6 \%}$ \\
\hline 18. Gün & $-0,28 \%$ & $0,63 \%$ & $-0,22 \%$ & $0,77 \%$ & $0,02 \%$ & $0,35 \%$ & $\mathbf{0 , 1 2 \%}$ \\
\hline 19. Gün & $0,09 \%$ & $-0,55 \%$ & $0,20 \%$ & $-1,01 \%$ & $3,83 \%$ & $0,00 \%$ & $\mathbf{0 , 1 2 \%}$ \\
\hline 20. Gün & $2,19 \%$ & $-0,98 \%$ & $-0,65 \%$ & $-2,53 \%$ & $0,66 \%$ & $0,01 \%$ & $\mathbf{0 , 4 4 \%}$ \\
\hline 21. Gün & $0,11 \%$ & $0,13 \%$ & $-3,63 \%$ & $-2,51 \%$ & $6,01 \%$ & $-1,06 \%$ & $\mathbf{- 0 , 2 4 \%}$ \\
\hline 22. Gün & $1,61 \%$ & $1,49 \%$ & $1,19 \%$ & $0,03 \%$ & $-4,50 \%$ & $-1,30 \%$ & $\mathbf{0 , 6 0 \%}$ \\
\hline 23. Gün & $-0,11 \%$ & $-2,39 \%$ & $0,00 \%$ & $1,38 \%$ & $-4,65 \%$ & $-0,56 \%$ & $\mathbf{- 1 , 0 2 \%}$ \\
\hline 24. Gün & $-0,63 \%$ & $0,84 \%$ & $1,54 \%$ & $0,52 \%$ & $-2,56 \%$ & $-0,16 \%$ & $\mathbf{0 , 0 1 \%}$ \\
\hline 25. Gün & $1,73 \%$ & $-0,83 \%$ & $0,55 \%$ & $-1,21 \%$ & $1,09 \%$ & $-0,32 \%$ & $\mathbf{0 , 4 5 \%}$ \\
\hline 26. Gün & $1,60 \%$ & $0,48 \%$ & $-0,42 \%$ & $0,60 \%$ & $-0,94 \%$ & $1,43 \%$ & $\mathbf{0 , 8 7 \%}$ \\
\hline 27. Gün & $-1,61 \%$ & $-0,17 \%$ & $2,32 \%$ & $1,19 \%$ & $2,43 \%$ & $-0,68 \%$ & $\mathbf{- 0 , 3 0 \%}$ \\
\hline 28. Gün & $0,39 \%$ & $0,02 \%$ & $0,36 \%$ & $-1,06 \%$ & $0,03 \%$ & $-0,04 \%$ & $\mathbf{0 , 1 6 \%}$ \\
\hline 29. Gün & $-0,12 \%$ & $-0,47 \%$ & $1,06 \%$ & $-1,45 \%$ & $0,68 \%$ & $-0,10 \%$ & $\mathbf{- 0 , 0 4 \%}$ \\
\hline 30. Gün & $0,38 \%$ & $0,82 \%$ & $1,38 \%$ & $0,16 \%$ & $-0,10 \%$ & $1,16 \%$ & $\mathbf{0 , 7 2 \%}$ \\
\hline
\end{tabular}

İlk defa halka arzı gerçekleşmiş ortaklık paylarının en kötü performansları ilk gün gerçekleşmiştir (-\%14,04). 2014 yılında ilk kez halka arz olan şirketlerin değeri ortalama \% 25,3 düşmüştür. 2013-2018 yılları arasında ilk halka arzı gerçekleşen ortaklık paylarının birinci günün sonunda ortalama \%14.04 değer kaybettiği ortaya çıkmıştır. 2018 yılı hariç 2013-2017 yılları arasında ilk halka arzı gerçekleştirilen payların tümünün yüksek fiyatlandığı söylenebilir. Yalnızca 2018 yılında düşük fiyatlama söz konusudur.

En yüksek getiri 2017 yılında halka arz olan şirketlerin 4. Gününde gerçekleşmiştir. $(\% 7,37)$ Genele bakıldığında en yüksek getiri yine halka arzın 4 . Gününde gerçekleşmiştir. $(\% 1,28)$

30 Günlük AR değerlerinin yıllara göre seyri Grafik 5' te görülebilir. 


\section{Y1llara Göre 30 Günlük AR Değeri}

$10,00 \%$

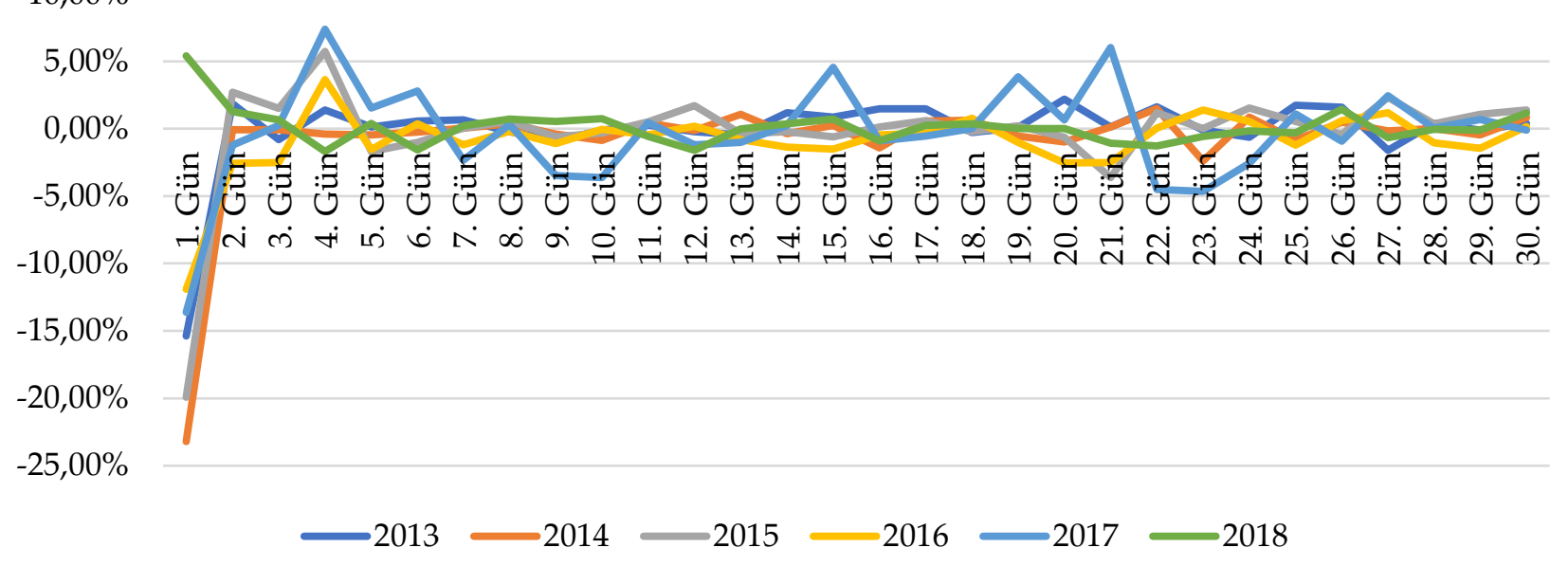

Grafik 5. Yıllara Göre 30 Günlük AR (Artık Getiri) Değeri

İlk defa halka arzı geçekleşmiş ortaklık paylarının işlem gördükleri pazara göre ilk 30 günlük fiyat performansları incelendiğinde Tablo 4 ' teki sonuçlara varılmıştır.

Tablo 4. İşlem Gördükleri Pazar Bazında 30 Günlük AR Değeri

\begin{tabular}{|c|c|c|c|c|c|}
\hline $\begin{array}{c}\mathrm{AR} \\
\text { Değeri }\end{array}$ & $\begin{array}{l}\text { Ana } \\
\text { Pazar }\end{array}$ & $\begin{array}{c}\text { Gelişen } \\
\text { İşletmeler Pazarı }\end{array}$ & $\begin{array}{l}\text { Kolektif Yatırım Ürünleri ve } \\
\text { Yapılandırılmış Ürünler Pazarı }\end{array}$ & $\begin{array}{l}\text { Yildiz } \\
\text { Pazar }\end{array}$ & Genel Toplam \\
\hline 1. Gün & $-11,57 \%$ & $-5,32 \%$ & $-16,27 \%$ & $-24,52 \%$ & $-14,04 \%$ \\
\hline 2. Gün & $-2,28 \%$ & $4,66 \%$ & $1,52 \%$ & $-0,69 \%$ & $1,07 \%$ \\
\hline 3. Gün & $-0,94 \%$ & $0,80 \%$ & $0,47 \%$ & $-0,65 \%$ & $-0,05 \%$ \\
\hline 4. Gün & $1,44 \%$ & $0,02 \%$ & $1,94 \%$ & $2,18 \%$ & $1,28 \%$ \\
\hline 5. Gün & $-0,38 \%$ & $-0,26 \%$ & $-0,77 \%$ & $0,58 \%$ & $-0,14 \%$ \\
\hline 6. Gün & $0,37 \%$ & $0,32 \%$ & $-0,57 \%$ & $0,51 \%$ & $0,22 \%$ \\
\hline 7. Gün & $0,42 \%$ & $-0,25 \%$ & $0,28 \%$ & $-0,57 \%$ & $-0,09 \%$ \\
\hline 8. Gün & $-0,35 \%$ & $0,72 \%$ & $-0,32 \%$ & $0,11 \%$ & $0,13 \%$ \\
\hline 9. Gün & $-0,51 \%$ & $-1,23 \%$ & $-1,50 \%$ & $0,50 \%$ & $-0,64 \%$ \\
\hline 10. Gün & $-0,25 \%$ & $0,11 \%$ & $-0,10 \%$ & $-1,26 \%$ & $-0,39 \%$ \\
\hline 11. Gün & $0,00 \%$ & $0,08 \%$ & $-1,00 \%$ & $1,18 \%$ & $0,18 \%$ \\
\hline 12. Gün & $-1,36 \%$ & $-1,00 \%$ & $1,34 \%$ & $0,40 \%$ & $-0,27 \%$ \\
\hline 13. Gün & $0,09 \%$ & $0,69 \%$ & $-0,34 \%$ & $-0,69 \%$ & $-0,01 \%$ \\
\hline 14. Gün & $0,90 \%$ & $0,40 \%$ & $-0,59 \%$ & $0,47 \%$ & $0,35 \%$ \\
\hline 15. Gün & $1,42 \%$ & $1,75 \%$ & $-0,47 \%$ & $-0,43 \%$ & $0,67 \%$ \\
\hline 16. Gün & $-0,53 \%$ & $1,10 \%$ & $-0,48 \%$ & $-0,70 \%$ & $-0,04 \%$ \\
\hline 17. Gün & $2,43 \%$ & $0,43 \%$ & $0,45 \%$ & $0,01 \%$ & $0,76 \%$ \\
\hline 18. Gün & $0,56 \%$ & $-0,49 \%$ & $1,44 \%$ & $-0,39 \%$ & $0,12 \%$ \\
\hline 19. Gün & $0,92 \%$ & $0,50 \%$ & $-1,18 \%$ & $-0,09 \%$ & $0,12 \%$ \\
\hline 20. Gün & $0,72 \%$ & $1,08 \%$ & $-0,16 \%$ & $-0,11 \%$ & $0,44 \%$ \\
\hline 21. Gün & $-0,52 \%$ & $1,50 \%$ & $0,07 \%$ & $-2,22 \%$ & $-0,24 \%$ \\
\hline 22. Gün & $-0,35 \%$ & $0,31 \%$ & $0,62 \%$ & $1,68 \%$ & $0,60 \%$ \\
\hline 23. Gün & $-1,24 \%$ & $-0,60 \%$ & $-0,92 \%$ & $-1,38 \%$ & $-1,02 \%$ \\
\hline 24. Gün & $-1,93 \%$ & $0,55 \%$ & $0,38 \%$ & $0,66 \%$ & $0,01 \%$ \\
\hline 25. Gün & $0,07 \%$ & $2,11 \%$ & $-0,44 \%$ & $-0,56 \%$ & $0,45 \%$ \\
\hline
\end{tabular}


G. Yaşar - B. Terim - C. Kayalı 12/4 (2020) 3965-3980

\begin{tabular}{|l|c|c|c|c|c|}
\hline 26. Gün & $-1,01 \%$ & $-0,93 \%$ & $2,11 \%$ & $-0,57 \%$ & $\mathbf{- 0 , 3 0 \%}$ \\
\hline 27. Gün & $0,76 \%$ & $2,27 \%$ & $0,27 \%$ & $-0,27 \%$ & $\mathbf{0 , 8 7 \%}$ \\
\hline 28. Gün & $0,64 \%$ & $0,43 \%$ & $-0,20 \%$ & $-0,29 \%$ & $\mathbf{0 , 1 6 \%}$ \\
\hline 29. Gün & $-0,90 \%$ & $0,40 \%$ & $0,41 \%$ & $-0,17 \%$ & $\mathbf{- 0 , 0 4 \%}$ \\
\hline 30. Gün & $1,56 \%$ & $0,15 \%$ & $0,29 \%$ & $1,00 \%$ & $\mathbf{0 , 7 2 \%}$ \\
\hline
\end{tabular}

İlk halka arzı gerçekleşen ortaklık payları işlem gördüğü pazara göre incelendiğinde en yüksek getiriyi 30 gün sonunda en az fon toplanan GIP (Gelişen İşletmeler Pazarı) şirketleri sağlamıştır (\%10,30). En düşük getiri ise en çok fon toplanan yıldız pazarda işlem gören ortaklık payları sağlamıştır (\%-26.27). Günler bazında en yüksek getiri GiंP' te işlem gören şirketlerin 2. gününde sağlanmıştır $(\% 4,66)$. Yıldız Pazar'da işlem gören şirketler ilk gün ortalama \%24,52 zarar etmişlerdir.

30 Günlük AR değerlerinin işlem gördükleri pazar bazındaki yıllara göre seyri Grafik $6^{\prime}$ da, şirket bazında ortalama getiri ile toplanan fon miktarı arasındaki ilişki de Grafik 7’ de gösterilmeye çalışılmıştır.

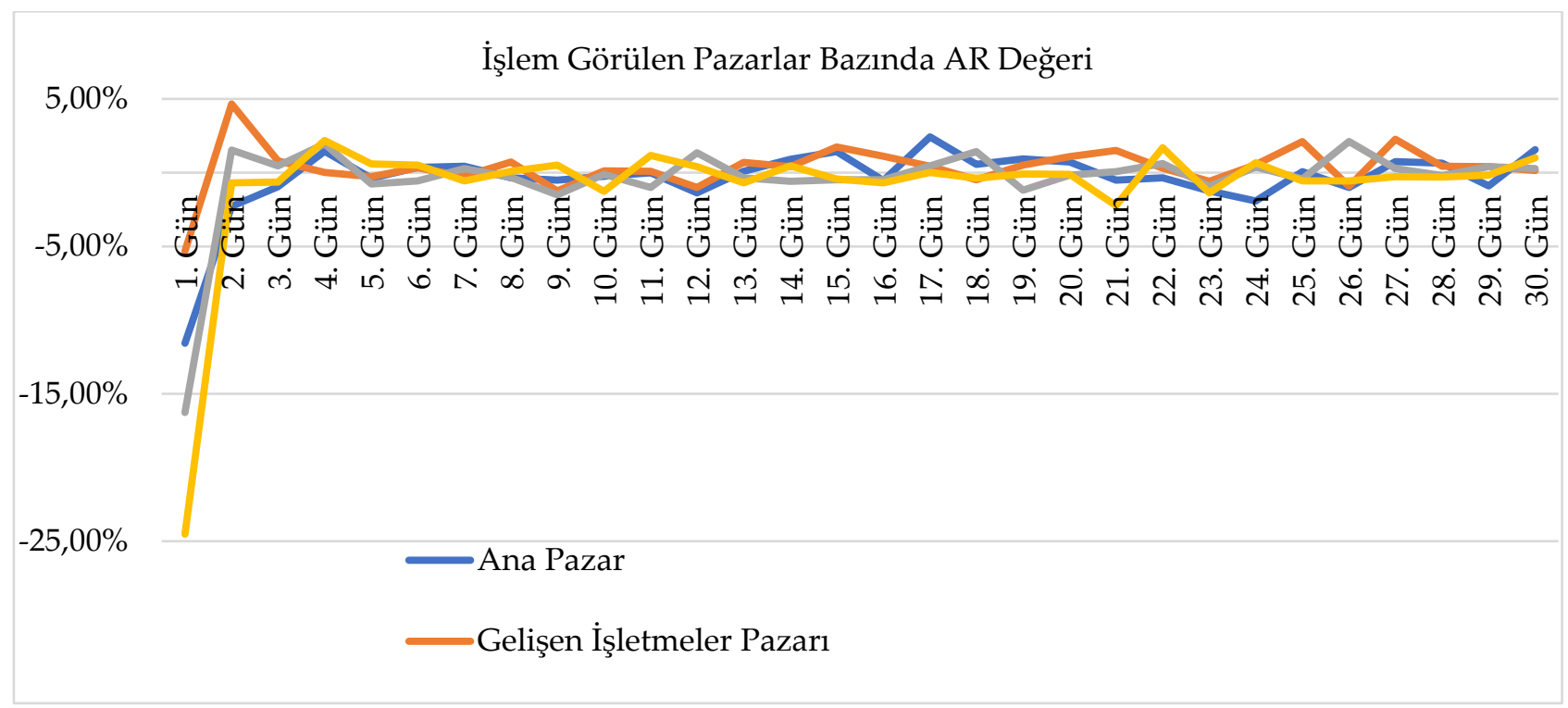

Grafik 6. İşlem Gördüğü Pazar Bazında 30 Günlük AR (Artık Getiri) Değeri

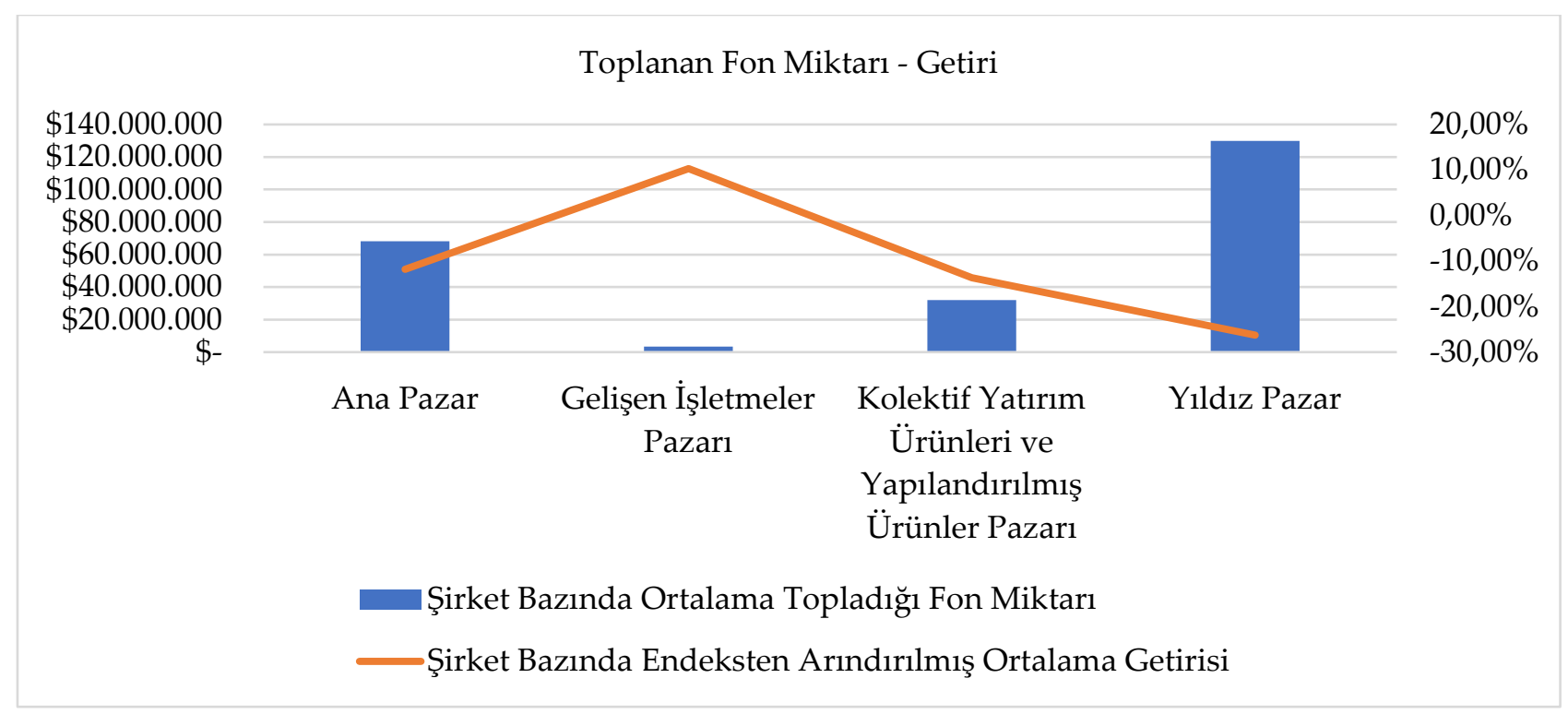

Grafik 7. Şirket Bazında Ortalama Getiri - Toplanan Fon Miktarı

Gelişen İşletmeler Pazarında işlem gören ortaklık payları ilk 30 günde en yüksek performansı gösteren paylar olmuşlardır. En düşük getiriyi sırasıyla Yıldız Pazar, Kolektif Yatıım Ürünleri ve Yapılandırılmış Ürünler pazarı ile Ana Pazar' da işlem gören ortaklık payları sağlamıştır. 
G. Yaşar - B. Terim - C. Kayalı 12/4 (2020) 3965-3980

İlk halka arzı gerçekleşmiş ortaklık paylarının endeks etkisinden arındırılmamış getirileri ve o tarihlerdeki BİST 100 Endeksinin Ham getirisi Grafik 8' deki gibi gerçekleşmiştir.

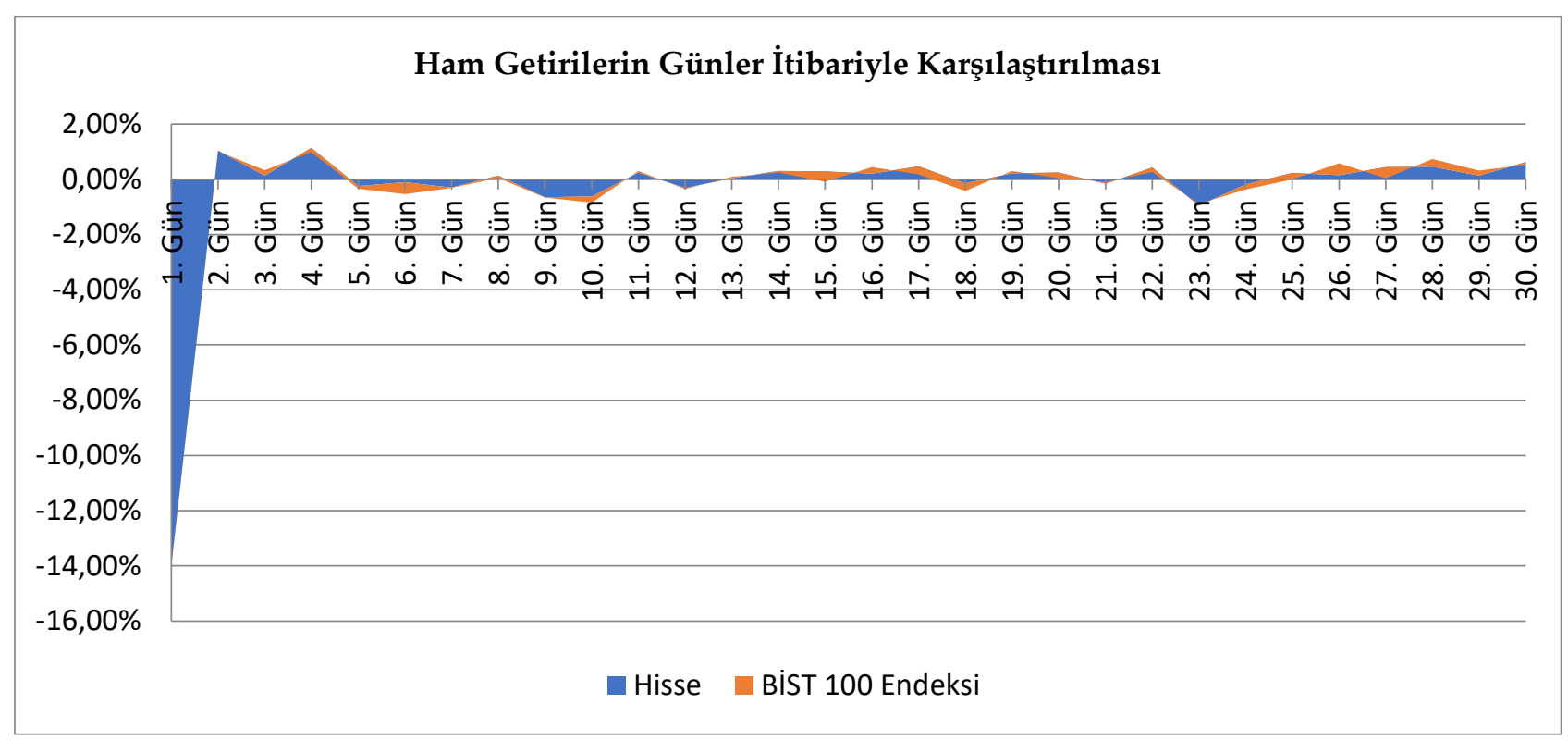

Grafik 8. Ham Getirilerin Günler İtibariyle Karşılaştııılması

İlk halka arzı gerçekleşmiş ortaklık paylarının endeks etkisinden arındırılmamış getirileri ile endeks etkisinden arındırılmış getirileri ise Grafik 9' daki gibi gerçekleşmiştir.

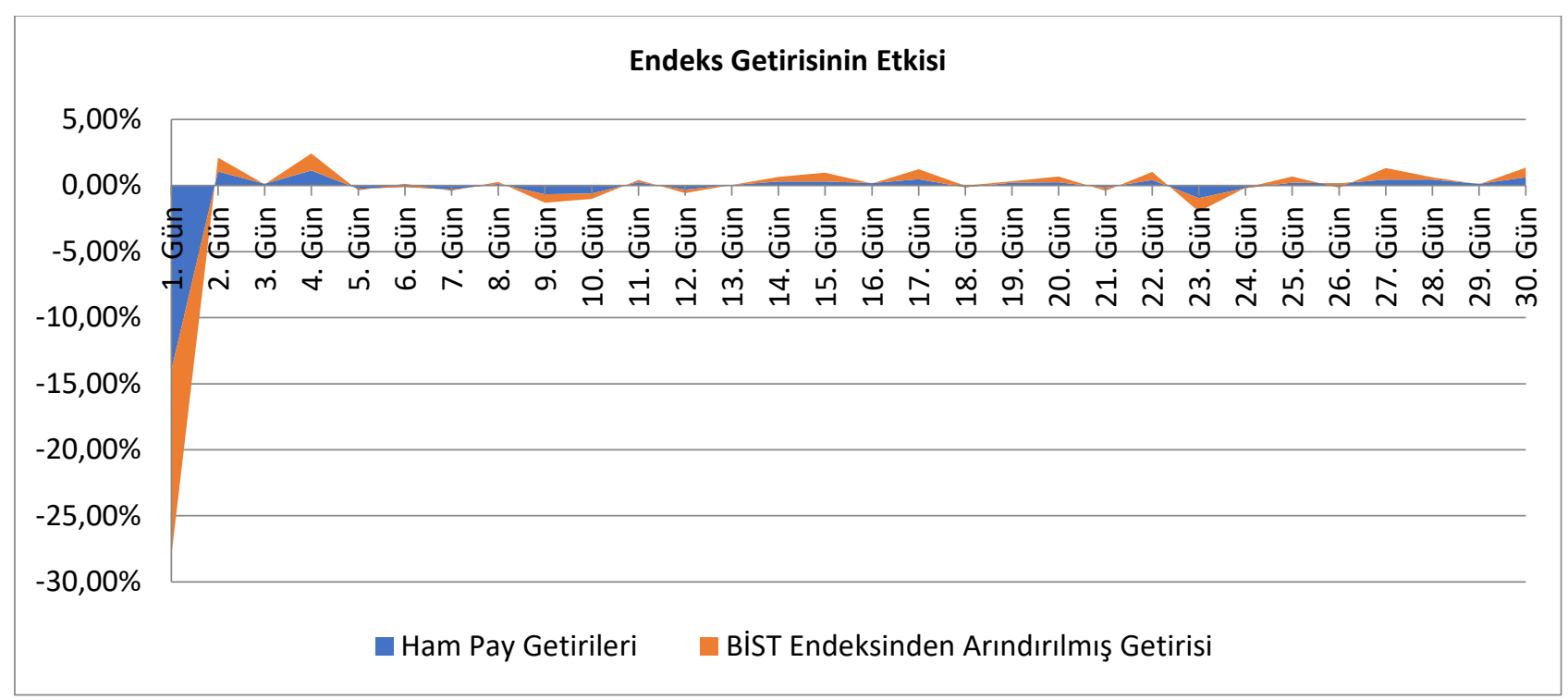

Grafik 9. Ham Getirilerin ve Endeks Etkisinden Arındırılmış Getirilerin Günler İtibariyle Karşılaştırılması

Grafik 8 ve Grafik 9'dan da görülebileceği gibi 2013-2018 yılları arasında payları ilk kez halka arz olan ortaklıkların, endeksten bağımsız ilk günkü kötü performansları kısa dönemli getirilerini sınırlamışlardır. Halka ilk kez arz olan paylar ilk 30 işlem günü içinde endeks getirisinin gerisinde kalmışlardır denilebilinir.

2013-2018 yılları arasında ilk 30 işlem günü sonunda halka arz edilmiş 50 şirket hissesinden 22'si endeks etkisinden arındırılmış pozitif getiri elde etmiştir. 28 şirket ise negatif getiri elde etmiştir.

İlk gün performanslarına bakıldığında 19 şirketin payları endeks etkisinden arındırılmış pozitif getiri elde ederken, 31 şirket de negatif getiri elde etmiştir.

2013-2018 yılları arasında halka arz edilen ortaklık paylarının kümülatif getirisi ise Tablo 5’ teki gibi olmuştur. 
Tablo 5. 2013-2018 Yılları BISTT Endeksinden Arındırılmış Kümülatif Getiriler

\begin{tabular}{|l|c|c|c|c|c|c|}
\hline Kümülatif Artık Getiri & 2013 & 2014 & 2015 & 2016 & 2017 & 2018 \\
\hline 1. Gün & $-15,38 \%$ & $-23,20 \%$ & $-19,92 \%$ & $-11,91 \%$ & $-13,62 \%$ & $5,40 \%$ \\
\hline 2. Gün & $-13,54 \%$ & $-23,29 \%$ & $-17,21 \%$ & $-14,49 \%$ & $-14,83 \%$ & $6,68 \%$ \\
\hline 3. Gün & $-14,34 \%$ & $-23,37 \%$ & $-15,70 \%$ & $-17,01 \%$ & $-14,60 \%$ & $7,33 \%$ \\
\hline 4. Gün & $-12,96 \%$ & $-23,79 \%$ & $-9,98 \%$ & $-13,37 \%$ & $-7,23 \%$ & $5,63 \%$ \\
\hline 5. Gün & $-12,83 \%$ & $-24,26 \%$ & $-11,66 \%$ & $-14,90 \%$ & $-5,69 \%$ & $6,03 \%$ \\
\hline 6. Gün & $-12,27 \%$ & $-24,51 \%$ & $-12,68 \%$ & $-14,54 \%$ & $-2,91 \%$ & $4,46 \%$ \\
\hline 7. Gün & $-11,62 \%$ & $-24,47 \%$ & $-12,63 \%$ & $-15,72 \%$ & $-5,23 \%$ & $4,67 \%$ \\
\hline 8. Gün & $-11,84 \%$ & $-24,11 \%$ & $-12,07 \%$ & $-15,90 \%$ & $-4,93 \%$ & $5,37 \%$ \\
\hline 9. Gün & $-12,74 \%$ & $-24,51 \%$ & $-12,68 \%$ & $-17,00 \%$ & $-8,41 \%$ & $5,91 \%$ \\
\hline 10. Gün & $-12,85 \%$ & $-25,38 \%$ & $-13,01 \%$ & $-17,05 \%$ & $-12,02 \%$ & $6,65 \%$ \\
\hline 11. Gün & $-12,59 \%$ & $-24,96 \%$ & $-12,49 \%$ & $-17,53 \%$ & $-11,58 \%$ & $6,06 \%$ \\
\hline 12. Gün & $-12,81 \%$ & $-25,11 \%$ & $-10,77 \%$ & $-17,33 \%$ & $-12,77 \%$ & $4,46 \%$ \\
\hline 13. Gün & $-13,26 \%$ & $-24,05 \%$ & $-11,15 \%$ & $-18,16 \%$ & $-13,79 \%$ & $4,44 \%$ \\
\hline 14. Gün & $-12,08 \%$ & $-24,43 \%$ & $-11,38 \%$ & $-19,52 \%$ & $-13,53 \%$ & $4,79 \%$ \\
\hline 15. Gün & $-11,23 \%$ & $-24,19 \%$ & $-11,98 \%$ & $-21,02 \%$ & $-8,97 \%$ & $5,50 \%$ \\
\hline 16. Gün & $-9,76 \%$ & $-25,60 \%$ & $-11,86 \%$ & $-21,47 \%$ & $-9,86 \%$ & $4,61 \%$ \\
\hline 17. Gün & $-8,28 \%$ & $-25,03 \%$ & $-11,25 \%$ & $-21,82 \%$ & $-10,42 \%$ & $4,86 \%$ \\
\hline 18. Gün & $-8,56 \%$ & $-24,40 \%$ & $-11,47 \%$ & $-21,04 \%$ & $-10,40 \%$ & $5,20 \%$ \\
\hline 19. Gün & $-8,47 \%$ & $-24,95 \%$ & $-11,27 \%$ & $-22,05 \%$ & $-6,57 \%$ & $5,20 \%$ \\
\hline 20. Gün & $-6,28 \%$ & $-25,93 \%$ & $-11,92 \%$ & $-24,58 \%$ & $-5,90 \%$ & $5,21 \%$ \\
\hline 21. Gün & $-6,17 \%$ & $-25,80 \%$ & $-15,55 \%$ & $-27,08 \%$ & $0,11 \%$ & $4,14 \%$ \\
\hline 22. Gün & $-4,56 \%$ & $-24,32 \%$ & $-14,37 \%$ & $-27,05 \%$ & $-4,39 \%$ & $2,85 \%$ \\
\hline 23. Gün & $-4,68 \%$ & $-26,71 \%$ & $-14,37 \%$ & $-25,67 \%$ & $-9,04 \%$ & $2,28 \%$ \\
\hline 24. Gün & $-5,31 \%$ & $-25,86 \%$ & $-12,83 \%$ & $-25,15 \%$ & $-11,60 \%$ & $2,13 \%$ \\
\hline 25. Gün & $-3,58 \%$ & $-26,70 \%$ & $-12,28 \%$ & $-26,36 \%$ & $-10,52 \%$ & $1,80 \%$ \\
\hline 26. Gün & $-1,98 \%$ & $-26,21 \%$ & $-12,70 \%$ & $-25,76 \%$ & $-11,45 \%$ & $3,24 \%$ \\
\hline 27. Gün & $-3,59 \%$ & $-26,38 \%$ & $-10,39 \%$ & $-24,58 \%$ & $-9,03 \%$ & $2,56 \%$ \\
\hline 28. Gün & $-3,20 \%$ & $-26,36 \%$ & $-10,03 \%$ & $-25,64 \%$ & $-9,00 \%$ & $2,52 \%$ \\
\hline 29. Gün & $-3,31 \%$ & $-26,83 \%$ & $-8,97 \%$ & $-27,09 \%$ & $-8,31 \%$ & $2,42 \%$ \\
\hline 30. Gün & $-2,93 \%$ & $-26,00 \%$ & $-7,59 \%$ & $-26,92 \%$ & $-8,42 \%$ & $3,58 \%$ \\
\hline & & & & & & \\
\hline
\end{tabular}

Kümülatif Artık Getiri

$10,00 \%$

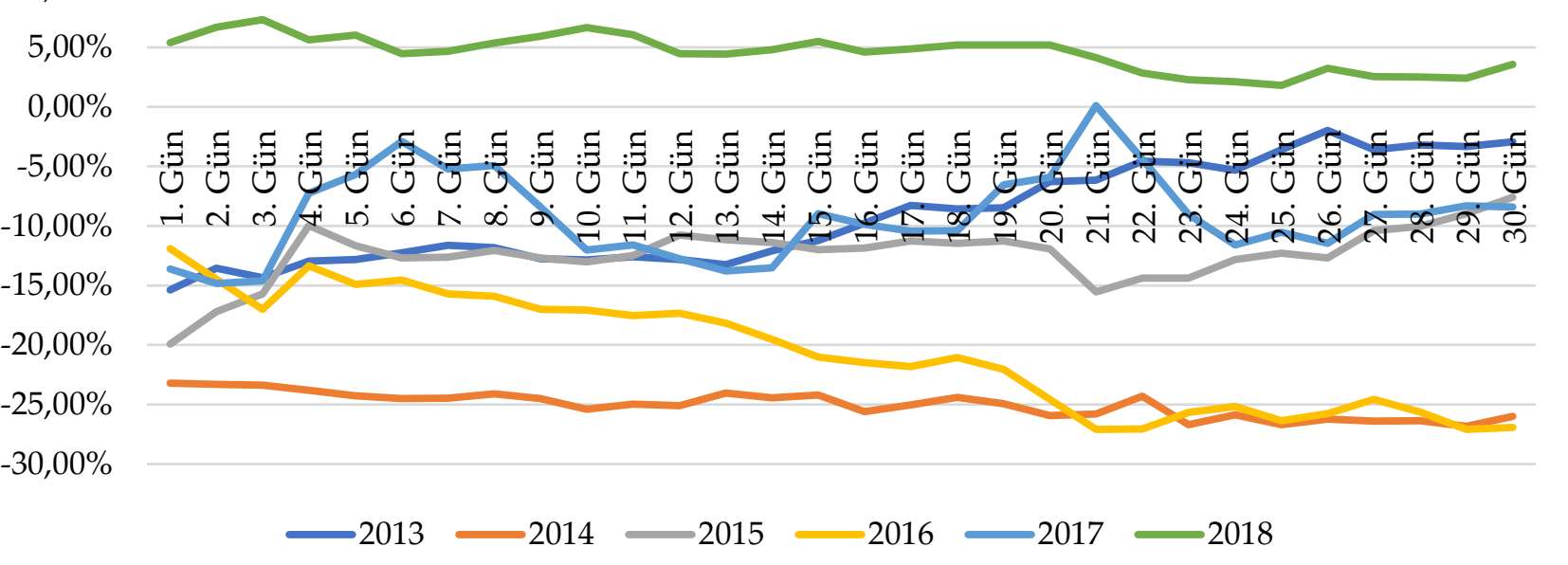

Grafik 10. 2013-2018 Yılları BİST Endeksinden Arındırılmış Kümülatif Getiri 


$$
\text { G. Yaşar - B. Terim - C. Kayalı 12/4 (2020) 3965-3980 }
$$

Tablo 5 ve Grafik 10'dan da görüleceği üzere 2013-2014-2015-2016 yıllarında ilk kez halka arzı gerçekleştirilen ortaklık paylarının değerleri, ilk 30 günde halka arz değerinin üzerine çıkamamıştır. 2017 yılında halka arz edilen paylar yalnızca 21. Gün halka arz değerinin üzerine çıkmış, daha sonra tekrar arz fiyatının aşağısına inmiştir. 2018 yılında halka arz edilen paylar ise ilk halka arz gününden itibaren primli halka arz olmuş, 30 gün boyunca halka arz fiyatının aşağısına düşmemiştir.

2013-2017 yılları arası halka arz olan ortaklık payları yüksek fiyatlanırken, 2018 yılında halka arz olan ortaklık payları negatif fiyatlanmıştır.

\section{SONUÇ VE TARTIŞMALAR}

Çalışmada 2013-2018 yılları arasında ilk defa halka arz edilen 50 ortaklık paylarının ilk 30 işlem günündeki performansları yıllara, halka arzı yapılan payların işlem gördüğü pazarlara ve BİST 100 Endeksine göre getirileri analiz edilmiştir.

2013-2018 yılları arasında ilk kez halka arzı yapılan ortaklık paylarına bakıldığında halka arzların büyük çoğunluğunun Gelişen İşletmeler Pazarı ve Yıldız Pazarda yapıldığı görülmektedir. Gelişen İşletmeler Pazarında halka açılan ortaklık paylarının da göreceli olarak küçük şirketlere ait oldukları belirlenmiştir.

İlk 30 günlük fiyat performanslarına bakıldığında ise yalnızca Gelişen İşletmeler Pazarında işlem gören ortaklık payları pozitif getiri elde etmişlerdir. Diğer pazarlarda işlem gören firmaların ilk 30 günlük ortalama getirileri halka arz fiyatının üzerine çıkamamıştır.

2010-2018 arasında ilk halka arzı gerçekleştirilen ortaklıklar, halka arz olduğu yıllara göre incelendiğinde, 2013-2014-2015 ve 2016 yıllarında fiyat performansları ilk 30 gün boyunca halka arz fiyatının üzerine hiç çıkamamışlardır. 2017 yılında halka arz olan firmaların ortalama getirileri 21. günde halka arz fiyatının üzerine çıkmış, ancak daha sonra tekrar halka arz fiyatının aşağısına düşmüştür. 2013-2014-2015-2016-2017 yıllarındaki 5 yıllık periyotta yapılan ilk halka arzların yüksek fiyatlandığı tespit edilmiştir. 2018 yılında yapılan halka arzların 1. günden itibaren pozitif getiri sağlamış olduğu ve düşük fiyatlama yapıldığı sonucuna varılmıştır.

Halka arz edilen ortaklık paylarının endeks etkisinden arındırılmış getirileri ile ham getirileri arasında çok büyük bir farklılığa rastlanmamıştır.

BİST 100 endeksi ve halka arz edilen payların ilk 30 günlük ham getirileri karşılaştırıldığında, halka arz edilen payların getirilerinin, endeks getirilerinin altında kaldığı saptanmıştır.

Halka ilk kez arzı gerçekleştirilen ortaklık payları ilk gün en kötü performanslarını göstermişlerdir. (2013-2018 ortalama -\%14,04) En yüksek ortalama getiriyi ise 4. Gün sonunda sağlamışlardır (\%1.28).

Değerlendirme sonucunda daha önce yapılan ve kısa dönemi kapsayan incelemelere benzer sonuçlara ulaşılmamış, bu çalışmada düşük fiyatlama tespit edilememiştir. 2013-2014-2015-2016 ve 2017 yıllarında yüksek fiyatlamanın, 2018 yılında ise düşük fiyatlamanın varlığının söz konusu olduğu söylenebilir.

Halka arzlarda görülen yüksek fiyatlama etkisi, gelişmiş ve gelişmekte olan piyasalardaki halka arzlara ilişkin verilerle karşılaştırıldığında, Türkiye' de yatırımcının halka arzlara olan yönelimini azaltmaktadır denilebilinir. Bu noktada ilk halka arzlarda, arza konu hisse senedine ilişkin optimum bir fiyatın, piyasa koşulları ve o dönemde piyasada işlem gören benzer şirketler ile karşılıklı değerlendirilerek saptanması ve böylelikle daha fazla yatırımcının katılımın sağlanması ile halka arz veriminin arttırılabileceği söylenebilir.

Bu bağlamda hisse senetleri halka arz edilen 2013-2018 yılları arasındaki şirketlerin, şirketin sektördeki büyüklüğü, sermaye piyasası içindeki konumu ve endeksteki ağırlığı, arz fiyatını ve ilk 30 günlük fiyat performansını etkilemekte olup, bu etkiler araştırılabilir. 


\section{KAYNAKÇA}

Altan, M. ve HOTAMIŞ, T.N. (2008). Türkiye'de Halka İlk Arzı Yapılan Hisse Senetlerinin Kısa Dönem Fiyat Performans Analizi (2000-2006), KMU İIBF Dergisi, 2008(1), 150-185.

Aydoğan K. ve Yıldırım J. (1992). İlk Defa Halka arz Edilen Hisselerin Fiyat Performansı, DPT, 3. İzmir İktisat Kongresi Tebliğleri, 4-7 Haziran 1992, İzmir,

Akkaşoğlu, V., (1992), Pricing of Initial Public Offerings, Master Tezi, Ankara, Bilkent Üniversitesi.

Aktaş, R., Karan M. B. ve Aydoğan K., (2003), Forecasting short run performance of initial public offerings in the İstanbul stock Exchange, Journal of Enterpreneurial Finance and Business Ventures, 8(1), 69-85.

Bayram, V.,(1995), Türkiye' de İlk Halka Arzların Kısa ve Uzun Dönem Performansı, Doktora Tezi, İstanbul, T.C. Marmara Üniversitesi Sosyal Bilimler Enstitüsü.

Bildik, R., ve Yılmaz M.K., (2008), The Market Performance of Initial Public Offerings in the İstanbul Stock Exchange, BDDK Bankacilı ve Finansal Piyasala Dergisi, 2, 49-77.

Çelik A., E., Sağlam G.Y., (2011), İMKB’ de Düşük Fiyatlama ve Aracılık Türü, Arz Yılı, Aracı Kurum Etkileri Üzerine Bir Araştırma, Doğuş Üniversitesi Dergisi, 12(2), 289-303.

Daştan D., (2008), Halka arzlarda Fiyatlandırma : 2004-2007 İMKB Örneği, Yüksek Lisans Tezi, Ankara, Ankara Üniversitesi Sosyal Bilimler Enstitüsü.

Durukan, M. B. (2002), The Relationship between IPO Returns and Factors Influencing IPO Performance: Case of the Istanbul Stock Exchange, Managerial Finance, 28, 18-38.,

Eraydın K., (2008), The Underpricing and Long Run Performance of Initial Public Offerings - Evidence from Turkey, Master Tezi, Lund-Scania, Lund University School of Economics and Management.

Erdem H., (1993), A Study on Price behaviour of Initial Public Offerings, Master Tezi, İstanbul, Boğaziçi Üniversitesi.

Erpek, Seda (2006), 2005 Yılında İMKB'de İlk Kez Halka Arz Edilen Hisse Senetlerinin Kısa Dönem Fiyat Performansları, SPK Yeterlik Etüdü, Ankara, Sermaye Piyasası Kurulu Denetleme Dairesi.

Güner N., Önder Z. ve Danışoğlu S., Underwriter Reputation and Short-Run IPO Returns: Evidence from an Emerging Market, Economic Research Center, METU International Conference on Economics 1999 Meeting, September 1999, Ankara,

Kırkulak, B. (2010). Uzun Dönemli Al ve Tut Getirileri: İMKB'de Halka Açık Şirketlerde Bir Uygulama, Ege Akademik Bakış Dergisi, 10, 465-486.

Kıymaz, H. (1996). Halka İlk Arz Edilen Hisse Senetlerinin Performansları: İmalat Sektörü 1990-1995 Uygulaması, İşletme ve Finans Dergisi, 3, 121-143.

Kıymaz, H. (1997). İMKB'de Halka Arz Edilen Hisse Senetlerinin Uzun Dönem Performansları ve Bunları Etkileyen Faktörler: İmalat Sektörü 1990-1995 Uygulaması, IMKB Dergisi, 3, 47-73.

Kiymaz, H. (2000). The Initial and Aftermarket Performance of IPO's in an Emerging Market: Evidence from Istanbul Stock Exchange, Journal of Multinational Financial Management, 10, 213- 227.

Küçükkocaoğlu, G. (2008). Underpricing in Turkey: A Comparison of the IPO Methods, International Research Journal of Finance and Economics, 13, 162-182.

Loughran, T., Ritter, J.R. and Rydqvist K. (1994). Initial Public Offerings: International Insights, Pacific-Basin Finance Journal, 2, 165-199, updated July 24, 2020.

Otlu, F. ve Ölmez S. (2011). Halka İlk Kez Arz Edilen Hisse Senetlerinin Kısa Dönem Fiyat Performansları ile Fiyat Performansını Etkileyen Faktörlerin İncelenmesi, İMKB'de Bir Uygulama, Akademik Yaklaşım Dergisi, 2, 14-44.

Özden O.E. (2005). The Initial and Long-run Price Performance of Initial Public Offerings: The Turkish Experience 1990-1997, Journal of Social Science Research, Fall 2005, University of Texas. 
G. Yaşar - B. Terim - C. Kayalı 12/4 (2020) 3965-3980

Özer M. (2014). 2011-2013 Döneminde Gerçekleştirilen Halka Arzların İşlem Görüşen Pazarlar İtibariyle Fiyat Analizi, Düşük Fiyatlamanın Nedenleri ve Uzun Dönem Performansı Etkileyen Unsurlar, Sorunlar ve Çözüm Önerileri, SPK Yeterlik Etüdü, Ankara, Sermaye Piyasası Kurulu Ortaklıklar Finansmanı Dairesi.

ÖZER B. (1999). Price Performance Of Initial Public Offerings In Turkey, Ankara, Sermaye Piyasası Kurumu Yayını, 128.

Sevim, Ş. ve Akkoç, S. (2006). İlk Halka Arzların Uzun Vadeli Performansları ve Ucuz Fiyat Olgusu: İstanbul Menkul Kıymetler Borsasında Sektörel Karşılaştırmalı Bir Uygulama, Dumlupınar Üniversitesi Sosyal Bilimler Dergisi, 16, 107-123

SPK, (2016). Halka Arz-SPK Yatırımcıları Bilgilendirme Kitapçıkları, SPK, Ankara.

SPK, (2018). Sermaye Piyasası Kurulu, Halka Açılma Sözlüğü, http://www.spk.gov.tr/Sayfa/Index/16/1 (Erişim Tarihi: 10 Kasım 2020)

Teker, S. ve Ekit, Ö. (2003). The Performance of IPO's in İstanbul Stock Exchange in Year 2000, Doğuş Üniversitesi Dergisi, 4(1), 117-128.

Tükel, A. (2010). Asimetrik Enformasyon Işı̆̆ında Halka Arzların Uzun Dönemli Performanslarının Değerlendirilmesi, İstanbul Üniversitesi İktisat Fakültesi Ekonometri ve İstatistik Dergisi, 12, 102-121

Ünlü, U. ve Ersoy E. (2008). İlk Halka Arzlarda Düşük Fiyatlama ve Kısa Dönem Performansın Belirleyicileri: 1995-2008 İMKB Örneği, Dokuz Eylül Üniversitesi İktisadi ve İdari Bilimler Fakültesi Dergisi, 23(2), 243258.

Ünlü U, Yıldız B., ve Yalama A. (2009). İlk Halka Arzlarda Uzun Dönem Getirilerinin Tahmini: Yapay Sinir Ağları ile İMKB için Ampirik bir Çalışma, İstanbul Üniversitesi İktisat Fakültesi Ekonometri ve İstatistik Dergisi, 10, 29-47

Yalçıner K. (2006). Düşük Fiyatlama Olgusu ile Halka Arz şekilleri ve Halka Arz Fiyatı Arasındaki İlişkinin Analizi: 1997-2004 Dönemine Ait Bir İnceleme, Gazi Üniversitesi İktisadi ve İdari Bilimler Fakültesi Dergisi, 7(2), 145-158.

Yazaroğlu B. (2015). 2010-2014 Yılları Arasında Halka Arz Edilen Hisselerin Kısa Dönem Performansları, Yüksek Lisans Tezi, Ankara, T.O.B.B. Ekonomi ve Teknoloji Üniversitesi-Sosyal Bilimler Enstitüsüİşletme Ana Bilim Dalı.

http://www.finnet.gen.tr

http://www.borsaistanbul.com/veriler 